\title{
Observation on dromedary (Camelus dromedarius) welfare and husbandry practices among nomadic pastoralists
}

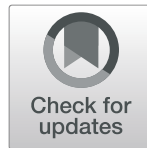

\author{
Maurizio Dioli, ${ }^{1,2}$
}

\begin{abstract}
Animal welfare is an important topic for consideration within every livestock husbandry sector. Welfare frameworks have recently been developed for intensively and semi-intensively husbanded dromedaries. These do not fit the reality of dromedaries under pastoral husbandry, and no specific analysis exists on dromedary welfare when reared under pastoral nomadic conditions. This article examines the existing husbandry practices utilised by nomadic pastoralists with the aim of improving the understanding of dromedary welfare in a nomadic pastoral husbandry system.
\end{abstract}

Keywords: animal welfare, livestock husbandry, indigenous technical knowledge, Ethnoveterinary practices

\section{Introduction}

The dromedary (Camelus dromedarius) or one-humped camel or simply camel is a widely distributed, common livestock species with a total world population, including the less common Bactrian camel (Camelus bactrianus) with which it hybridises easily (Dioli 2020, Imamura et al. 2017) exceeding 35 million heads (FAOSTAT 2020, Faye 2020). Camels are mainly used as a source of milk and meat in semi-intensive settings in peri-urban areas of many countries (Baidar et al., 2003, Fawi et al. 2017, Kuria et al. 2016, Nahid and Hadeel 2017, Schwartz and Dioli 1992) and in intensively managed systems in localised situations in UAE (Nagy and Juhasz 2016) and other countries (https://www.kamelenmelk.nl/en/camelmilk/, https://www.camilkdairy.com.au/). However, the overwhelming majority of camels are reared in a pastoralist nomadic environment (Schwartz and Dioli, 1992, Al Ani 2004a). Camel husbandry practices in these environments are very different from practices adopted in modern semi-intensive/intensive camel farming systems. They have evolved over thousands of years (Uerpmannh 1999),

Correspondence: camel4ever@fastemail.us

${ }^{1}$ MRCVS: member Royal College of Veterinary Surgeons, London, UK ${ }^{2}$ Indre Arna, Norway

\section{Springer Open}

dictated by the necessity of ensuring the survival of camel herders in a challenging and unforgiving environment. Many of the husbandry practices adopted in nomadic pastoral areas do not follow animal welfare guidelines adopted in Western livestock systems. To help in better understanding this reality, the author catalogues dromedary husbandry practices witnessed among nomadic pastoral communities of various African, Middle East and Asian countries and analyses their relationship with Western-based animal welfare guidelines.

\section{A general review of livestock welfare concepts}

Livestock welfare is a discipline encompassing several aspects of animal care from the physical and mental life of livestock to their physiology, productive functions and adaptations to various environments and their challenges. Animal welfare can be interpreted as the interrelationship between suffering, environment, life expectancy, responsiveness and stereotypical behaviour (Broom 1991). This led to the concept of animal welfare as an overlapping of three broad components: basic health and functioning, normal feelings with the absence of negative states, and natural living (Fraser et al. 1997, Fraser 2008). Livestock welfare is an essential requisite in 
modern livestock keeping, and it has been endorsed by the World Organisation for Animal Health with the Adoption of 10 'General Principles for the Welfare of Animals in Livestock Production Systems' (OIE, 2012). Welfare concepts have been further clarified with the development of the so-called Five Freedoms: freedom from hunger (and malnutrition) and thirst by ready access to fresh water and nutritious diet; freedom from discomfort (absence of physical and thermal discomfort) by providing shelter and comfortable resting areas; freedom from pain, injury and disease by prevention or rapid diagnosis and treatment; freedom to express normal behaviour by providing sufficient space, proper facilities and company to be able to express most natural patterns of behaviour; and freedom from fear and distress by ensuring conditions and treatment which avoid mental suffering (https://webarchive.nationalarchives.gov.uk/2012101 0012427/http://www.fawc.org.uk/freedoms.htm) (Farm Animal Welfare Council 2012, Mellor 2004, 2012, 2017, Mellor et al. 2009, Mellor and Beausoleil 2015, Mellor and Reid 1994, Mellor and Stafford 2001). More recently, this model has been further developed to include humananimal interactions (Mellor et al. 2020). Unfortunately, notwithstanding this increased awareness of animal welfare, the camel has not received much attention (Pastrana et al. 2020). Large camelids (C. dromedarius, C. bactrianus) are not mentioned in the Animal Welfare Section 7 of the Terrestrial Animal Health Code of the World Organization of Animal Health/OIE (OIE 2019) nor in the welfare assessment protocols developed by the EU Welfare Quality ${ }^{\circ}$ research project (Welfare Quality Network 2009). Currently, only three articles have been published on camel welfare, all on camels kept under semi-intensive management (Padalino and Menchetti 2021, Pastrana et al. 2020, Previti et al. 2016) with no reference at all to camels kept under extensive nomadic pastoralist management.

\section{Baseline realities of dromedary husbandry among nomadic pastoralists}

Free-range livestock keeping in semi-arid areas has evolved in response to unpredictable levels of rainfall within an annual cycle of dry and rainy seasons (Western and Finch 1986). The availability of livestock forage is therefore irregular, and livestock are regularly exposed to periods of hunger during the dry/winter season or starvation in case of drought. Livestock night enclosures, when provided, are often very basic, and livestock are routinely exposed to thermal and predator stresses (Schwartz and Dioli 1992). In arid areas, livestock access to drinking water is often severely limited, as watering points are normally several walking days away from the grazing areas, so all livestock, particularly in the dry season, are regularly exposed to thirst. In addition, nomadic pastoral areas are often too remote to be provided with clinical veterinary services, and therapeutical, anaesthetic and antiinflammatory drugs are rarely available (Köhler-Rollefson et al. 2001). Diseases, parasites and the pain and distress that can be associated with these pathogens are therefore a regular common occurrence (Schwartz and Dioli 1992).

\section{Review of common restraining practices}

Short-term physical restraint of adult animals can be achieved with a simple lip hold (Fig. 1a). For longer periods, various methods are adopted to physically restrain dromedaries. A simple and widespread practice adopted for a standing camel consists of flexing one front leg at the carpal joint and tying it in such a position with a rope (Fig. 1b). This will immobilise the animal in a standing position while allowing it to couch if it feels the need. Other common restraining practices consist of tying both the front legs at knee height or over the fetlock (Fig. 1c-e). Front leg hobbles are also adopted particularly to control movements of aggressive males during their rutting period, and in such cases, the hobbles are much sturdier and also tethered to a ground stake with a rope several metres long (Fig. $1 \mathrm{f}-\mathrm{h}$ ). This is an ancient technique used ubiquitously in all pastoral areas of Africa and Asia for hundreds of years, as illustrations in historical manuscripts demonstrate (Fig. 2). If a more complete immobilisation is required once a camel is couched, a rope connected to a front leg is passed over the neck and tied to the other leg, so neck movement is severely limited (Fig. 3a). Among some pastoralists, the propensity for aggressiveness of a male in rut is controlled by applying a permanent tourniquet in the throat area (Fig. 3b). A variety of leg restraints are also used not to completely immobilise an animal but simply to facilitate control of the animal, allowing the camel to walk but hindering faster gaits. A common method is to tie both legs on one side of the camel to each other or to tie two camels together by their neck with a loose rope (Fig. 3c, d). An additional method used in camels who consistently escape the herd involves applying a very tight, thin rope over the fetlock of a front leg. This area expands when weight is applied to the foot during walking increasing the tightness of the rope. While uncomfortable, it is tolerable in case of a normal walk but will get much worse with a faster gait, persuading the animal to resume normal walking (Fig. 3e).

\section{Welfare considerations on restraint practices}

The restraining practices that are adopted to immobilise camels are similar in many areas of the world (Schwartz and Dioli 1992, Al Ani, 2004a, b, Rathore 1986, Ranjan et al. 2017). The majority of practices are well-tolerated and pose no risk for the animal's welfare with the important warning that any restraint should not be used for an excessive length of time and that the material used in the 

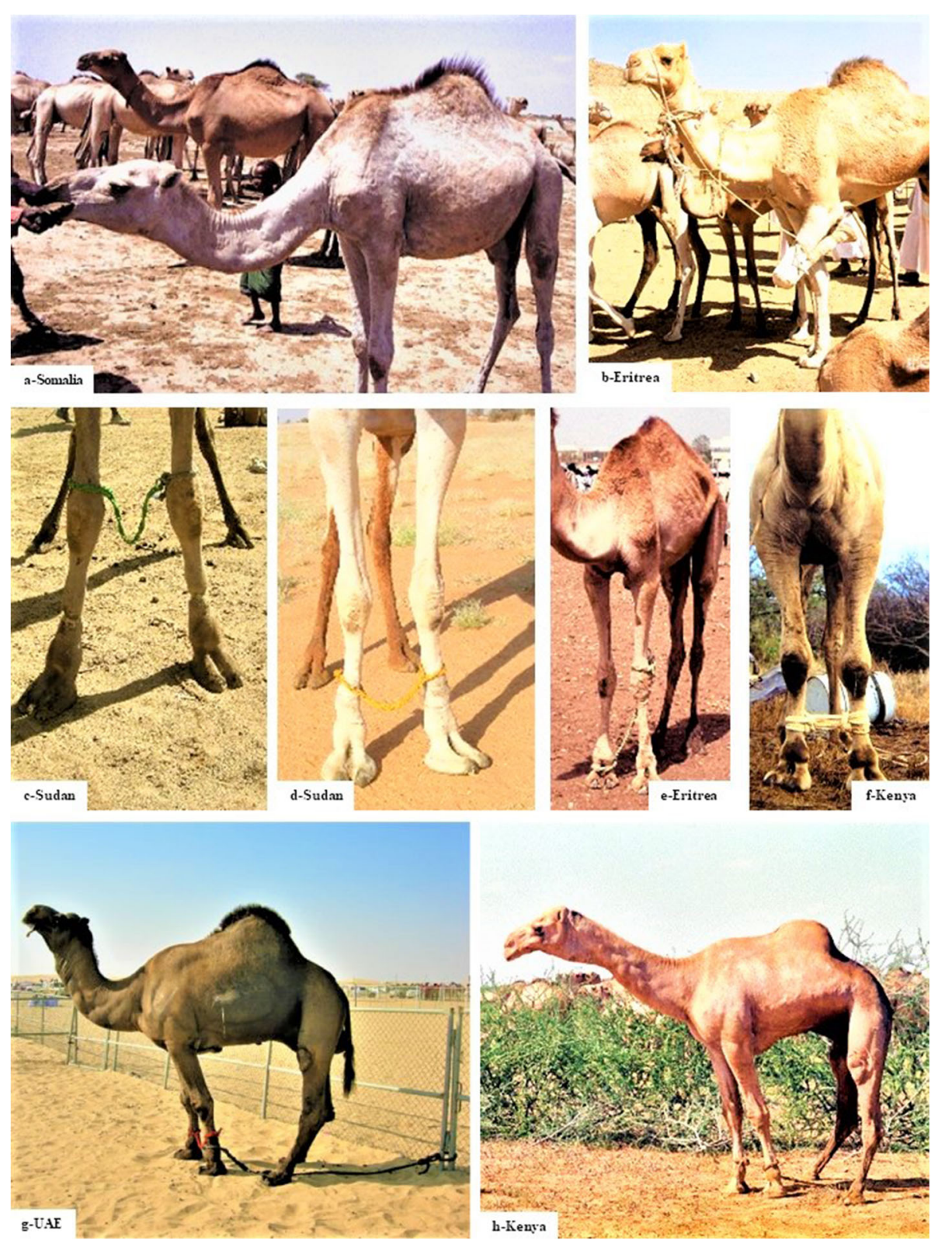

Fig. 1 Images of various camel restraints and control practices used by nomadic camel pastoralists in a variety of countries (Dioli 2012, 2013, Schwartz and Dioli 1992). a Somalia. b, e Eritrea. c, d Sudan. f, h Kenya. g UAE

restraining ropes not be abrasive. Ropes made with nylon or other plastic material should not be used because they can cause serious wounds (Fig. 1c-e). The methods of hobbling and tethering a bull in rut are of ancient origin (Fig. 2) and today are extremely widespread in all camel-raising countries and ethnic groups. The practice should be of critical welfare concern because it constrains the camel's natural behaviour and limits its freedom of movement and the possibility of exercise. In addition, the limited range of movement and the prolonged social isolation facilitate the development of abnormal postures and behaviours typical of camels kept in semi-intensive systems (Padalino et al.
2014). An additional tool of welfare assessment on the issue of camel hobbling may be provided by noting the approach used for another large animal: equids. The National Equine Welfare Council (UK) considers the prolonged tethering of horses a problem for their welfare (NEWC 2006). Similarly, the prolonged or permanent tethering of animals such as horses is forbidden by various legislation such as the 2020 Australian Prevention of Cruelty to Animal Regulation (https://agriculture.vic.gov.au/livestock-and-animals/ animal-welfare-victoria/pocta-act-1986/victorian-codes-ofpractice-for-animal-welfare/code-of-practice-for-thetethering-of-animals-revision-2) and by the Australian 


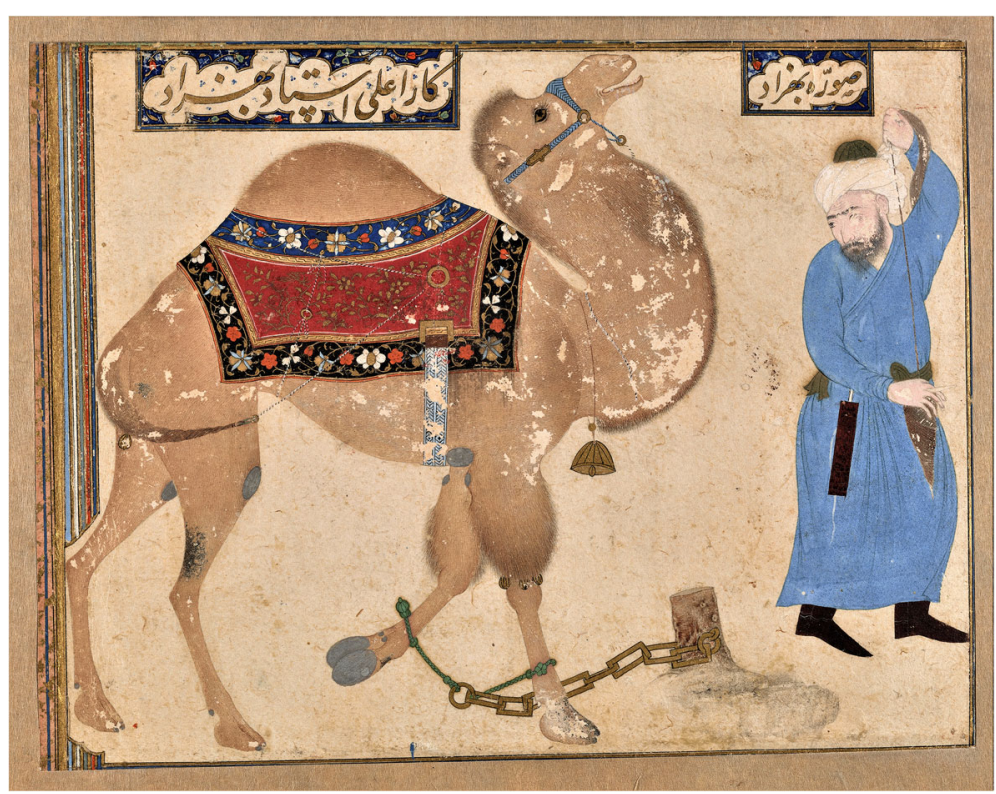

Fig. 2 Fettered camel and keeper, ascribed to Bizhad, late fifteenth century, Afghanistan, Herat, courtesy of the Freer Gallery of Art and Arthur M. Sackler Gallery-Smithsonian. https://asia.si.edu/object/F1937.22/

Horse Welfare Protocol which state that "Tethering and hobbling of horses should only be a short term practice" and "hobbled horses should not be tethered" (https://www. ashs.com.au/media/1802/horse-welfare-protocol-policy. pdf). Ultimately, all restraining methods whose mode of action is based on causing pain and discomfort (Fig. 3b, e) represent a welfare concern because, while not causing permanent damage, they negatively affect the welfare of the animal.

\section{Review of common control practices}

Control methods in dromedaries involve the use of various headgear; however, the classic horse bridle with the "bit", the item that goes across the mouth of a horse, is not suitable for use in dromedaries because it interferes with lower jaw lateral movements during grazing/browsing. The most widespread implement used for control is a simple halter, or a rope tied to the lower jaw (Fig. 3e, f). When more precise control of the animal is needed, a variety of implements have been devised, all of them utilising the sensitivity of the lips and nose area to mechanical stimuli. Nose rings are commonly used in many African countries while in Asia, nose plugs are the preferred option (Figs. 3g, h, 4 a, b) (Ranjan et al. 2017). Occasionally, a simple thin rope tied to one of the lips to exert control over the animal is sufficient (Fig. 4c). Among Bactrian camel (Camelus bactrianus) pastoralists, a much more radical implement is used. The nasal septum is pierced between or just under the nostrils with a thin implement, and a large wooden peg is permanently inserted once the wound is healed (Fig. 4e).

\section{Welfare considerations on control practices}

All styles of halters are welfare-compliant provided that they are made up of a suitable non-abrasive material and not left on permanently. Halters made of nylon or plastic ropes should always be avoided because the material can easily cause serious skin wounds (Fig. 4d). The use of nose rings and nose plugs is a very ancient husbandry practice (Fig. 5) still widely used today. Its welfare impact is negligible on the condition that is not misused as a tool to physically restrain a camel. If used in such a way, it will often result in traumatic lacerations of the area (Fig. $4 \mathrm{a}, \mathrm{b})$ particularly if the end of the "nose line" is too robust and does not break in case of a sudden movement of the animal. The use in many Asian countries of a large wooden peg across the nasal septum in Bactrian camels may be compared to the steel nose "bull ring" inserted into the nasal septum to control bulls and adopted in cattle husbandry practices worldwide. The practice is a painful procedure and causes considerable trauma to delicate anatomical structures, therefore representing a serious challenge to the welfare of the Bactrian camels. While it may be deemed necessary, this practice should be carried out by a veterinarian with the use of local anaesthetics and with a proper post-operative procedure. This recommendation is in line with what is advised for a similar procedure in cattle by virtually all animal welfare regulatory bodies and associations such as RSPCA (https://kb.rspca.org.au/knowledge-base/what-does-therspca-think-of-nose-rings-for-pigs-and-bulls/). 

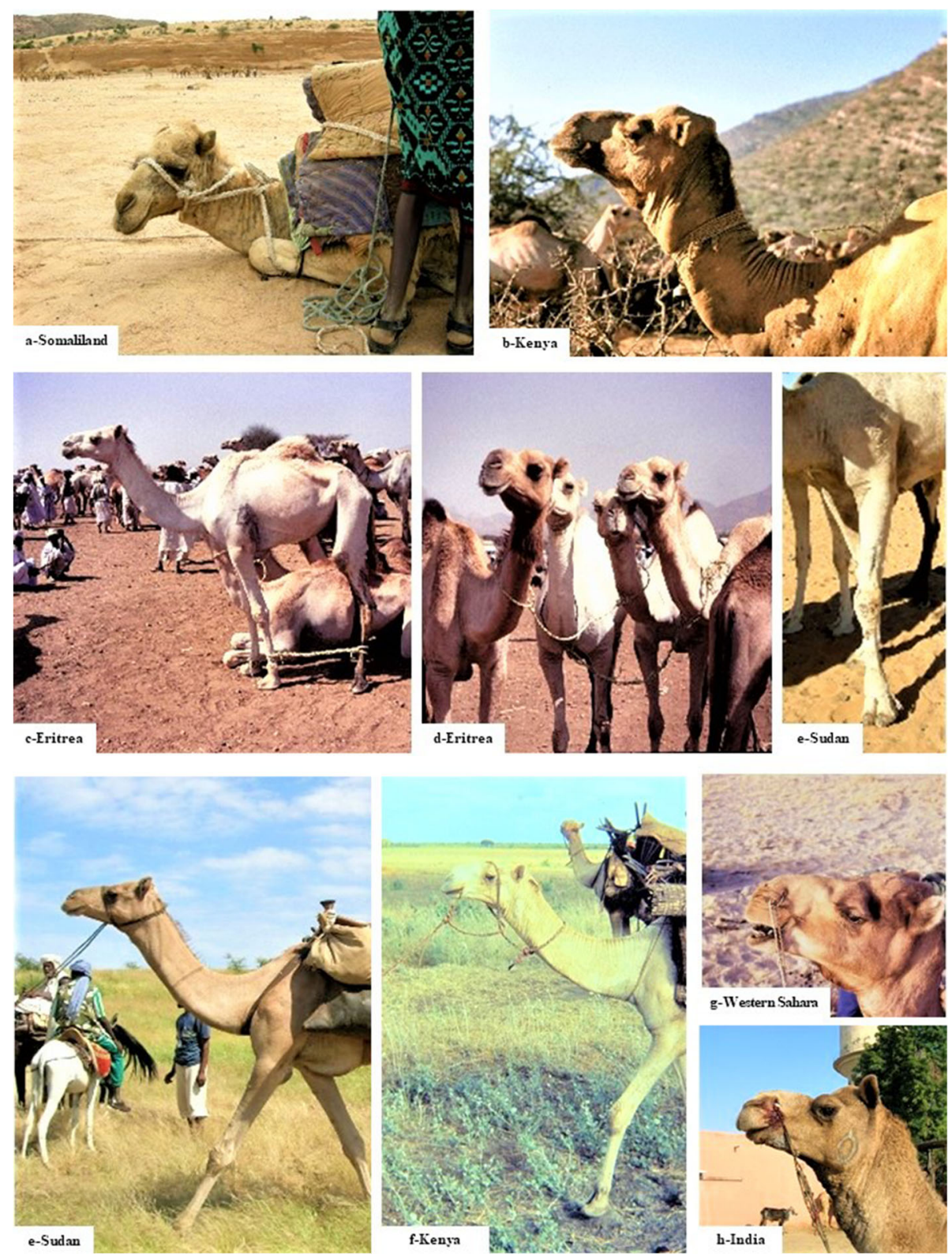

Fig. 3 Images of various camel restraints and control practices used by nomadic camel pastoralists in a variety of countries (Dioli 2012, 2013, Schwartz and Dioli 1992). a Somaliland. b, f Kenya. c, d Eritrea. e Sudan. g Western Sahara. h India

\section{Review of common milking practices}

Dromedaries are commonly used as milking animals; however, their milk let-down reflex is not as well developed as in modern milking cattle, and the presence of the calf is almost always required to stimulate milk letdown (Dioli 1992). In addition, it is not unusual for first parity lactating camels to resist being milked by trying to avoid or kick the human milkers. To keep the camel stationary for milking, pastoralists frequently flex one frontal leg at the carpal joint and tie it in such a position with a rope (Fig. 4f). A camel in such a position is generally unable to kick. However, a more radical method to prevent kicking consists of applying ropes on the rear legs, over the knee joint or in the tarsal areas (Fig. 6a-c). Dromedary biting attempts during milking are discouraged by attaching hanging wooden plugs to the ears. Any quick movement of the camel's head such as turning to her side to attempt to bite the milker causes the implements to sway and hit the camel's face confusing her and deterring any further movement (Fig. 6d). The camel lactation and milk let-down reflex are strongly regulated by the presence of the calf. The death of a calf usually means the absence of the milk let-down reflex rendering milking impossible. Pastoralists can artificially 

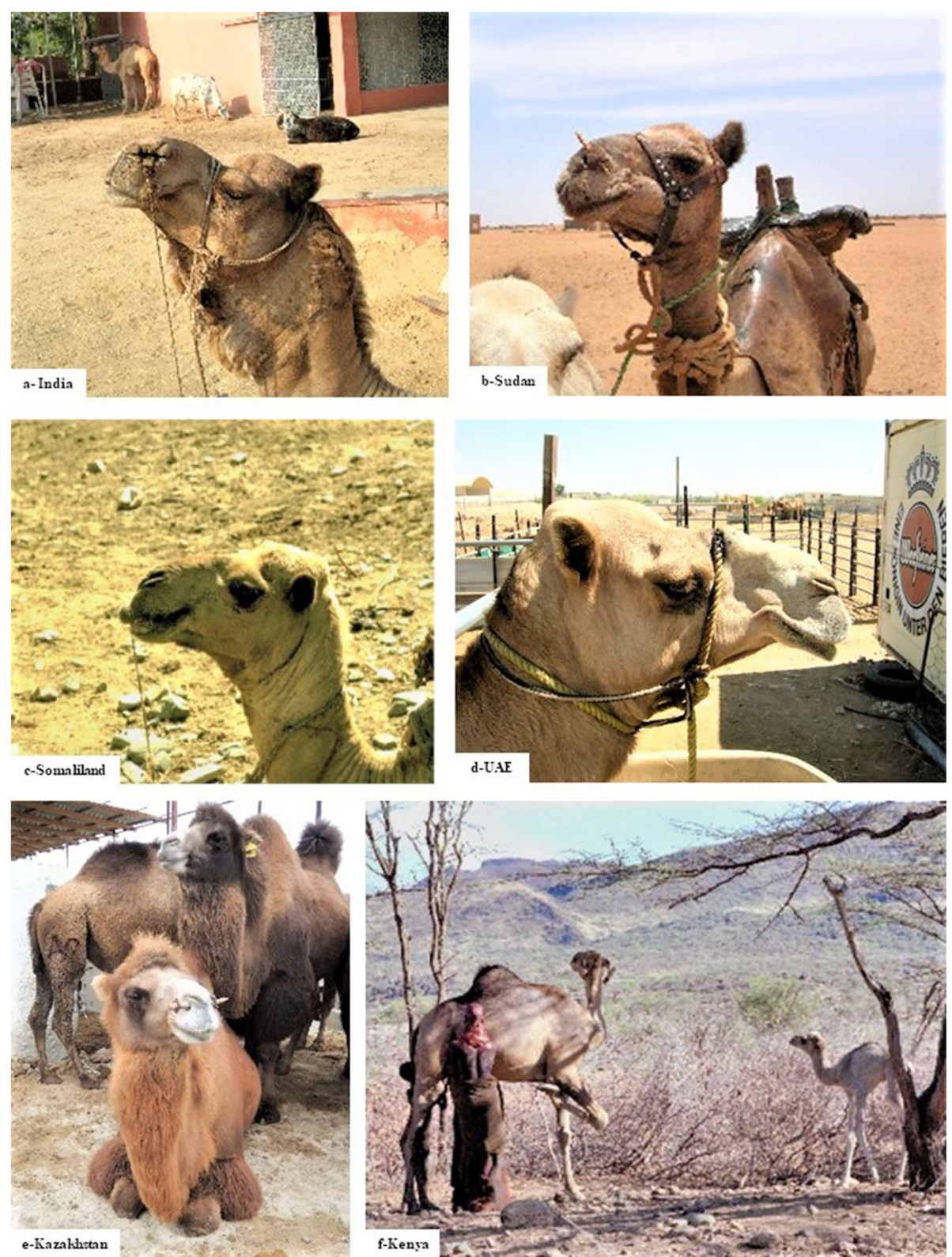

Fig. 4 Images of various camel restraints and control practices used by nomadic camel pastoralists in a variety of countries (Dioli 2012, 2013, Schwartz and Dioli 1992). a India. b Sudan. c Somaliland. d UAE. e Kazakhstan. f Kenya

recreate a milk let-down reflex by, at the usual time of milking, mechanically blocking the anus and briefly stopping defecation. The implements commonly used for this technique are two smooth flat pieces of wood that are tied over each other trapping the skin surrounding the anus (Fig. 6e). The practice is widespread in all camel-keeping pastoral cultures of the Horn of Africa, and it likely originated by mimicking the practice of "cow insufflation": the technique of stimulating milk letdown in cattle by blowing air into the cow's vagina. This custom is widespread and routinely used in Africa (Dupire 1962, Evans-Pritchard, 1937, Schapera and
Farrington 1933), Arabia (Thomas 1932) and Asia (Sierksma, 1962) (Fig. 7) and well-known since prehistoric times (Le Quellec 2011, Lucas 1989). The practice of insufflation as a tool to provoke the milk let-down reflex has been proven to work because blowing air into the vagina elicits a powerful stimulus for oxytocin release (Schams et al. 1982) that subsequently initiates the milk let-down.

Camel calves are frequently kept with their mother. A common method used by pastoralists to control the calf milk offtake is to cover the udder with an "udder net" or to cover the calf's mouth with a net (Fig. 6f, g). 


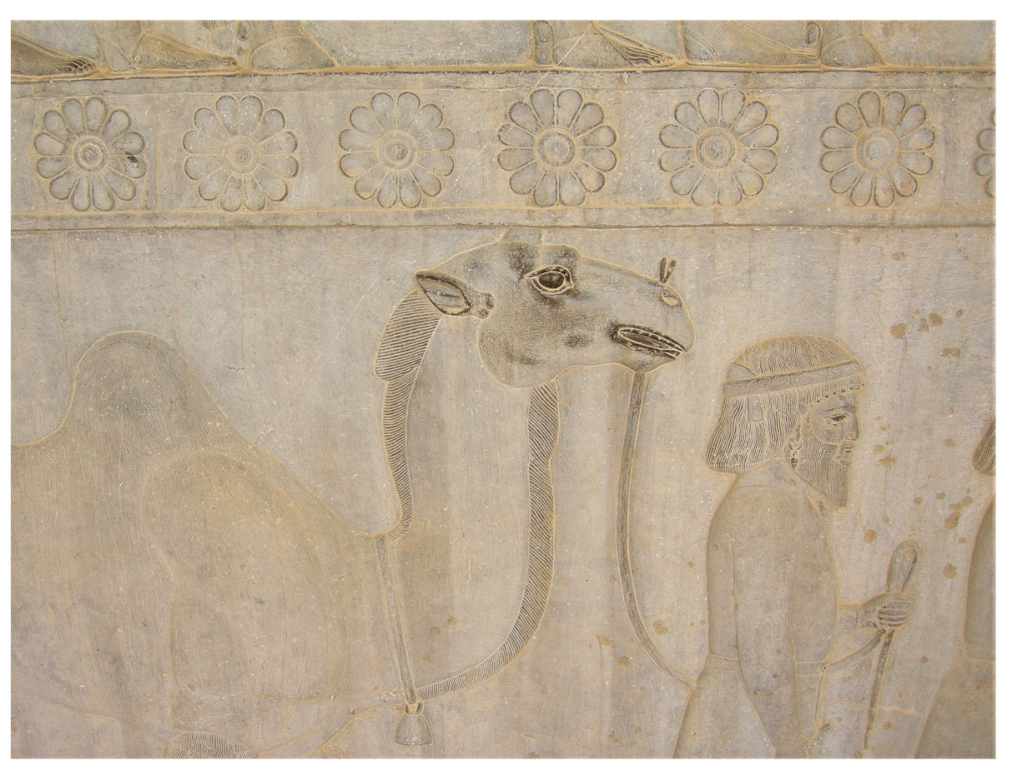

Fig. 5 A bassrelief from the audience hall of Persepolis showing a Bactrian camel being offered as a gift to the Persian king (c. 515 B.C.). Note the use of a nose peg to lead the animal (Dioli 2013)

Alternatively, one or all the udder teats are tied with thin strips of bark or cloth to which a wooden spike is sometimes added to discourage the calf from suckling (Fig. $6 \mathrm{~h}, \mathrm{i})$. These implements are left permanently on the teats and briefly removed only when the camel needs to be milked. Once the milking is finished the calf is allowed to suckle for a short time, to empty the udder of any residual milk, and then the teats are tied up again.

\section{Welfare considerations on milking practices}

An obvious welfare issue is the custom of blocking the anus of a lactating camel who lost her calf to elicit the milk let-down reflex. Among modern-day veterinary legal establishments, the practice of "cow insufflation" is not approved because it may cause discomfort to the animal and, furthermore, is deemed unnecessary because there are medicines registered for use to stimulate milk let-down. Cow insufflation is therefore not listed as a "recognised veterinary practice" by the Royal College of Veterinary Surgeons UK (RCVS) because it is an "uncomfortable procedure that will cause pain, suffering, distress or lasting harm". Indeed, in several Asian countries, cow insufflation or phooka or doom dev, as it is known in India, Pakistan and Bangladesh, is a practice forbidden to be performed in cattle and other milk animals by various legislation against animal cruelty (India: http:// www.fao.org/faolex/results/details/en/c/LEX-FAOC039976/ \#: :text=59\%20of\%201960).,prevention\%20of\%20cruelty\%20to\%20animals.\&text=It\%20rules\%20for\%20the\%20experiments,in\%20circuses\%20and\%20other\%20attractions; Pakistan: http://www.fao.org/faolex/results/details/en/c/ LEX-FAOC064057; Bangladesh: http://www.fao.org/faolex/
results/details/en/c/LEX-FAOC035755/). Tying the teats to prevent calf suckling also represents a welfare issue because the routine ligature of the teats often causes tissue trauma leading to udder pathologies such as mastitis or in serious cases teat necrosis (Fig. 6j).

\section{Review of common weaning practices}

Camel lactation is exceptionally long, regularly lasting over 12 months and often reaching 16 months (Dioli 2012), frequently extending into the late-term pregnancy of the next calf. It is unhealthy for a lactating camel to initiate a new lactation without any pause from the previous one. Allowing the lactating camel to reconstitute her body reserves in the provision of the next lactation is, therefore, important to ensure that the calf is weaned at a reasonable time (i.e. 12-14 months). To stop a calf from suckling, a common method used is tying all the teats with a rope with a long wooden spike attached; this ensures that the calf cannot grasp the teat and suckle (Fig. 6k). Several alternative methods include rendering the suckling uncomfortable to the mother, thus inducing a strong avoidance reaction to the calf's attempts to suckle. This is achieved by adding sharp spiked implements to the head/lips of the calf so that when the calf tries to suckle the udder, such implements will stab the udder (Fig. $8 \mathrm{a}-\mathrm{c}$ ). Other systems consist of curtailing the mobility of the calf lips therefore preventing the calf from grasping the teat. This is achieved by tightly tying a thin rope over one or both lips of the calf. The ensuing stoppage of blood circulation in the area will cause loss of sensitivity and motility of the lips preventing the calf from grasping the teat to suckle (Fig. 8d). The calf lip 

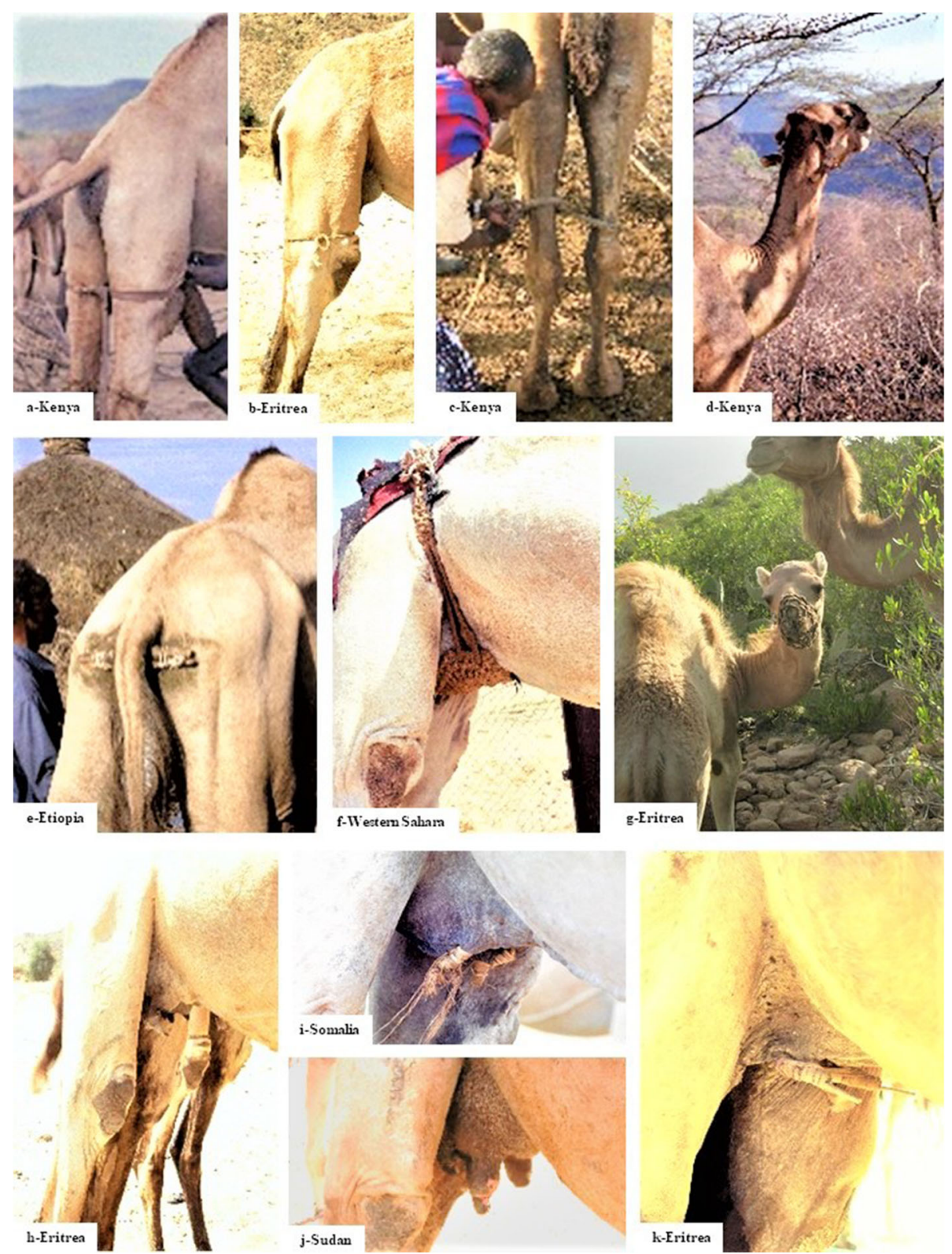

Fig. 6 Images of various camel milking and weaning practices used by nomadic camel pastoralists in a variety of countries (Dioli 2012,2013, Schwartz and Dioli 1992). a, c, d Kenya. b, g, h, k Eritrea. e Ethiopia. f Western Sahara. i Somalia. j Sudan

mobility can also be restrained more crudely by stitching the lips together (Fig. 8e). If such systems fail, more drastic methods can be adopted, all based on creating pain avoidance behaviour in the calf. A painful wound, made by cutting a strip of skin or burning, is made over the muzzle lip/nostrils areas of the calf. When the calf attempts to suckle, the wound, in contact with the udder, causes pain and forces the calf to abandon suckling (Fig. 8f-h). Alternative strategies to stop suckling consist of interfering with the tongue contraction movement that produces suction over the teat. This is achieved by placing a wooden peg across the mouth over the tongue kept in position by tying the sides with a rope passing under the jaw of the calf (Fig. 8i). Another effective, albeit cruel method to stop the tongue suction contractions uses a longitudinal cut across and over the upper middle part of the calf tongue just a few millimetres under the tongue mucosa (Fig. 8j). Hairs are inserted into the wound to ensure that the wound will not heal too quickly. The wound will cause pain whenever the tongue is contracted to produce suction for suckling. In areas where grazing is the only forage available, a simple implement consists of tying the calf halter with a short rope to a front foot; the weaning calf will be 


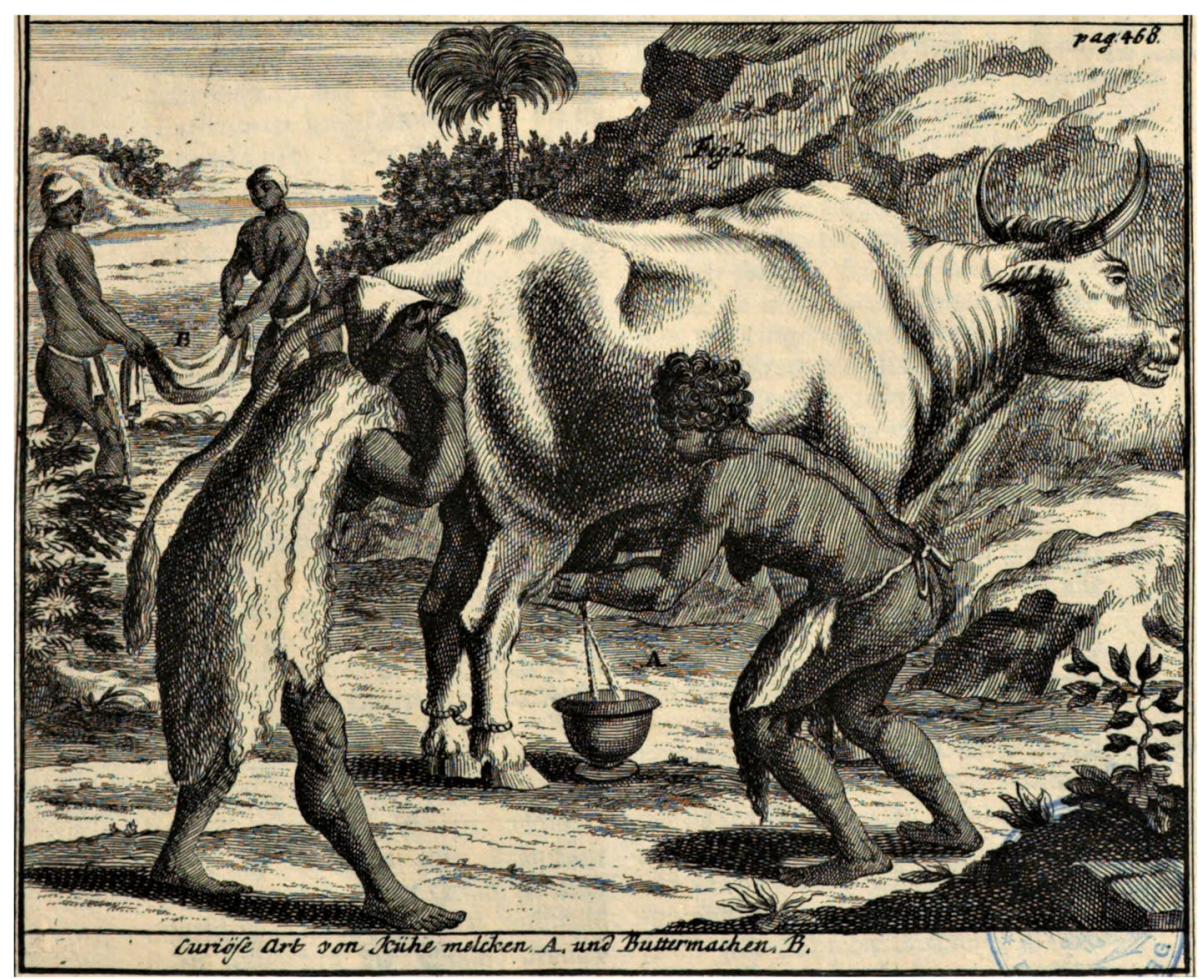

Fig. 7 Engraving from the book by Peter Kolb illustrating the practice of cow insufflation in his description of the "Hottentos" of the Cape (after Kolb 1719: 468) https://www.digitale-sammlungen.de/de/view/bsb11056194?page=523

able to graze but not to raise his head to reach the udder (Fig. 8k).

\section{Welfare considerations on weaning practices}

Many of the weaning methods used in camel pastoral areas mimic the common anti-suckling devices used in Western husbandry practice. Such implements consist of a nose weaning ring clamped to the septum with spike extensions that prevent the calf from nursing its mother because she will move away to avoid the spike when the calf tries to suckle. This weaning method is not ideal from an animal welfare perspective, but allowing the calf and the mother to remain in close physical contact is less stressful and is preferable to an abrupt separation or even to fence separation. However, any anti-suckling device based on such a system is acceptable only if it does not cause pain to the calf and does not prevent grazing. Unfortunately, many of the anti-suckling devices used by pastoralists do not respect such fundamental animal welfare criteria, causing pain and severe discomfort to the calf and therefore are not acceptable from a welfare point of view.

Review of common calf acceptance and fostering practices In the dromedary, calf presence and its suckling action are essential requirements for an abundant and long lactation (Dioli 2012). A calf death or rejection, a relatively common occurrence, may therefore negatively impact or even completely stop the lactation of its mother. Pastoralists have therefore developed numerous strategies to induce a camel who has rejected her newborn to accept it back or foster an unrelated calf. The simplest method consists of isolating the mother with her newborn calf in a simple enclosure some distance away from the herd, and then at sunset, a disguised herdsman stages the action and vocalisation of a predator attempting to enter the enclosure. The predator threat strongly stimulates the herd instinct of the mother encouraging her to bond with her calf. Another common method adopted is to limit the movements of the mother by tying her rear legs and often also her front legs to limit her ability to reject and so facilitating the calf access to her udder for suckling (Fig. 9a). A similar approach of movement limitation of the mother is adopted by flexing one of her front legs and tying it to the opposite leg (Fig. 9b). A slightly different method includes not only limiting the movements of the mother but also adding an element of mild discomfort by bending the fetlock of one front leg and tying it in an uncomfortable position with a tight rope (Fig. 9c). If none of these systems is successful, a more radical technique can be used. The method consists of occluding the anus by trapping the skin surrounding the anus using two smooth flat pieces of wood tied over each other and by partially blocking the nostrils by wrapping stripes of bark around them (Fig. 9d-f) (Dioli 2012, 

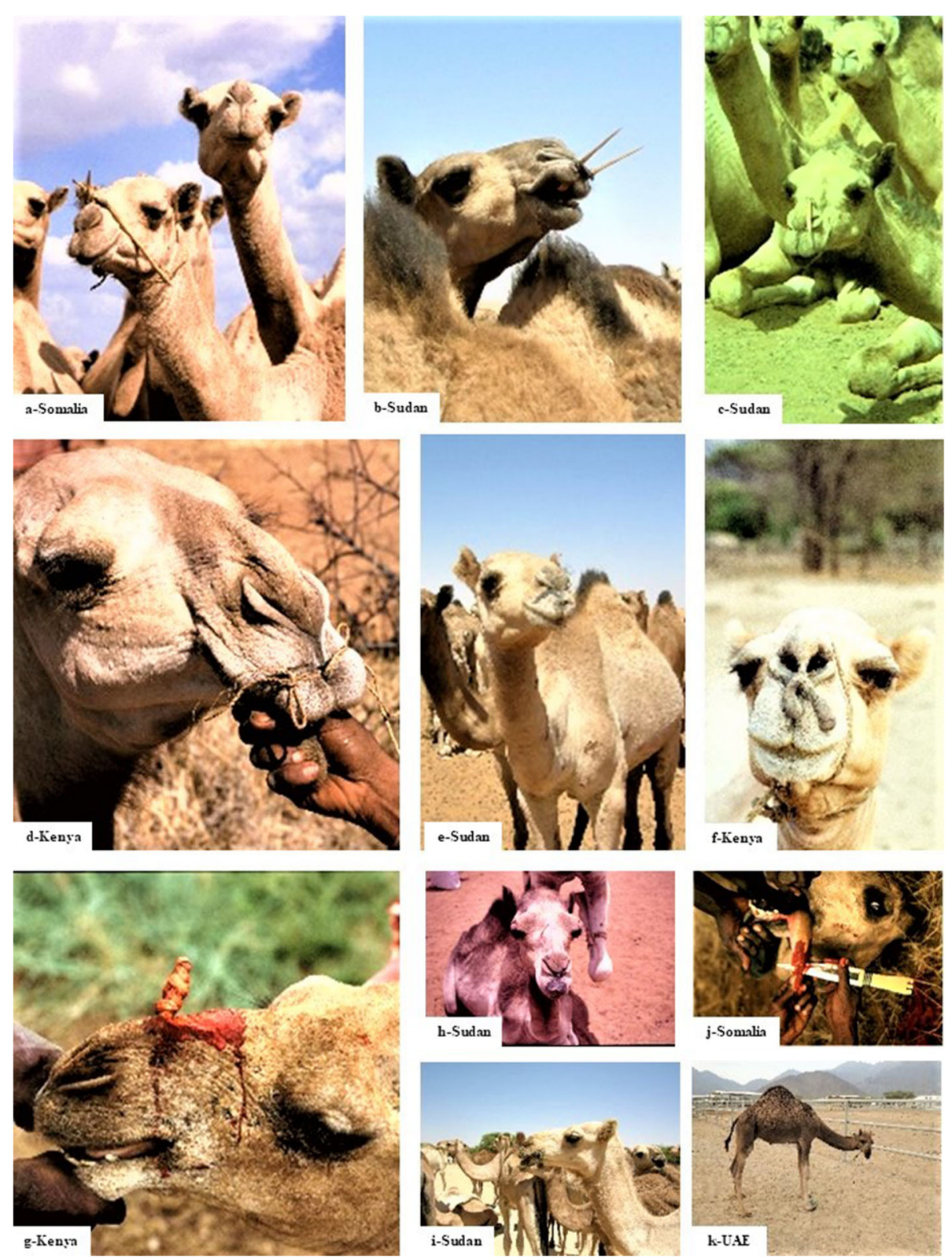

Fig. 8 Images of various camel milking and weaning practices used by nomadic camel pastoralists in a variety of countries (Dioli 2012,2013, Schwartz and Dioli 1992). a, j Somalia. b, c, e, h, i Sudan. d, f, g Kenya. k UAE

Schwartz and Dioli 1992). The implements are left in situ for several hours and removed swiftly as soon the camel exhibits a milk let-down reflex and allows the calf to suckle. The explanation behind the practical success of such unusual husbandry practice is not only explained by the fact that these implements cause serious discomfort and pain to the mother so numbing her efforts to reject the calf, but most importantly by the establishment of the "Ferguson reflex pathway" (Ferguson 1941). The pressure of the mass of faecal content accumulating in the blocked intestines causes vaginal/uterine stimulation and the physiological production of oxytocin with subsequent initiation of the milk let-down reflex (Schams et al. 1982). Among some pastoralists, this technique is modified, and instead of partially closing the nostrils, a rope is passed through the perforated nasal septum and then tied to a tree in an unnatural high position while the anus is blocked simply by tying a rope around the extended folds of the skin surrounding the anus (Fig. 9g). Occasionally, when the calf is born already dead, the adoption of a foster calf is achieved by restraining the mother and wrapping her head with a blanket to impede any vision and any contact with her dead calf. Subsequently, the freshly expelled placenta is 

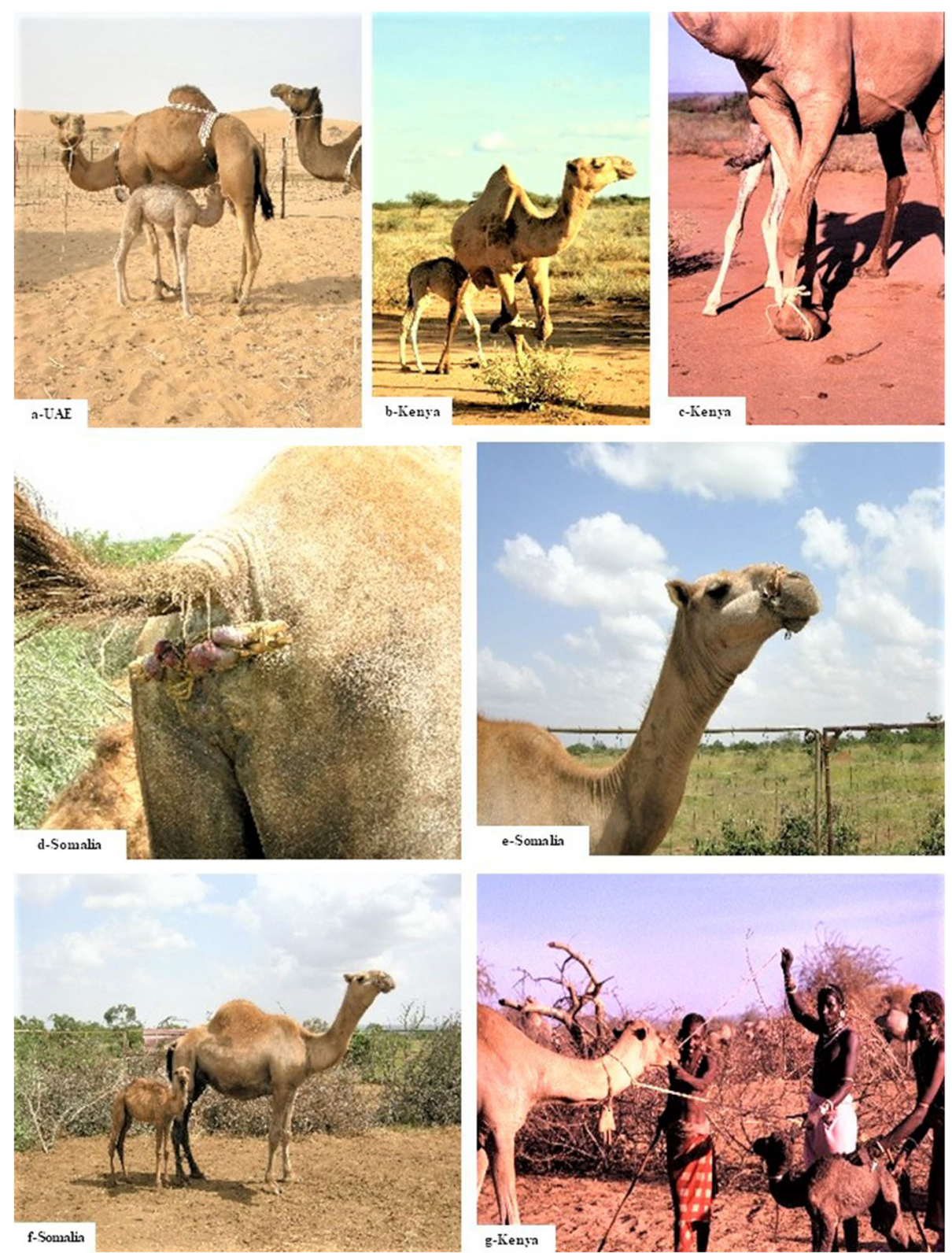

Fig. 9 Images of various camel milking and weaning practices used by nomadic camel pastoralists in a variety of countries (Dioli 2012,2013, Schwartz and Dioli 1992). a UAE. b, c, g Kenya. d-f Somalia

used to wipe the coat of a foster calf who then is placed in front of the camel while simultaneously removing the blindfold (Fig. 10a).

\section{Welfare considerations on calf acceptance and fostering practices}

From a welfare point of view, the only tolerable practices to induce calf acceptance and fostering are the ones that are based purely on enhancing the maternal instinct without using painful procedures. The time-limited use of restraining ropes on the mother to facilitate the calf nursing is also acceptable. However, all calf acceptance/ fostering techniques causing pain, psychological suffering, distress or lasting harm due to the risk of injury and infection, such as any artificial technique to provoke the development of the "Ferguson reflex pathway", are serious violations of animal welfare and are not acceptable.

\section{Review of common packing and riding practices}

Dromedaries are regularly used in pastoral nomadic areas as packing and riding animals (Fig. 10b, c). There are multiple riding and packing saddle styles positioned variedly over the withers, the hump or the lumbar areas (Dioli 2013). Information about the riding/carrying 

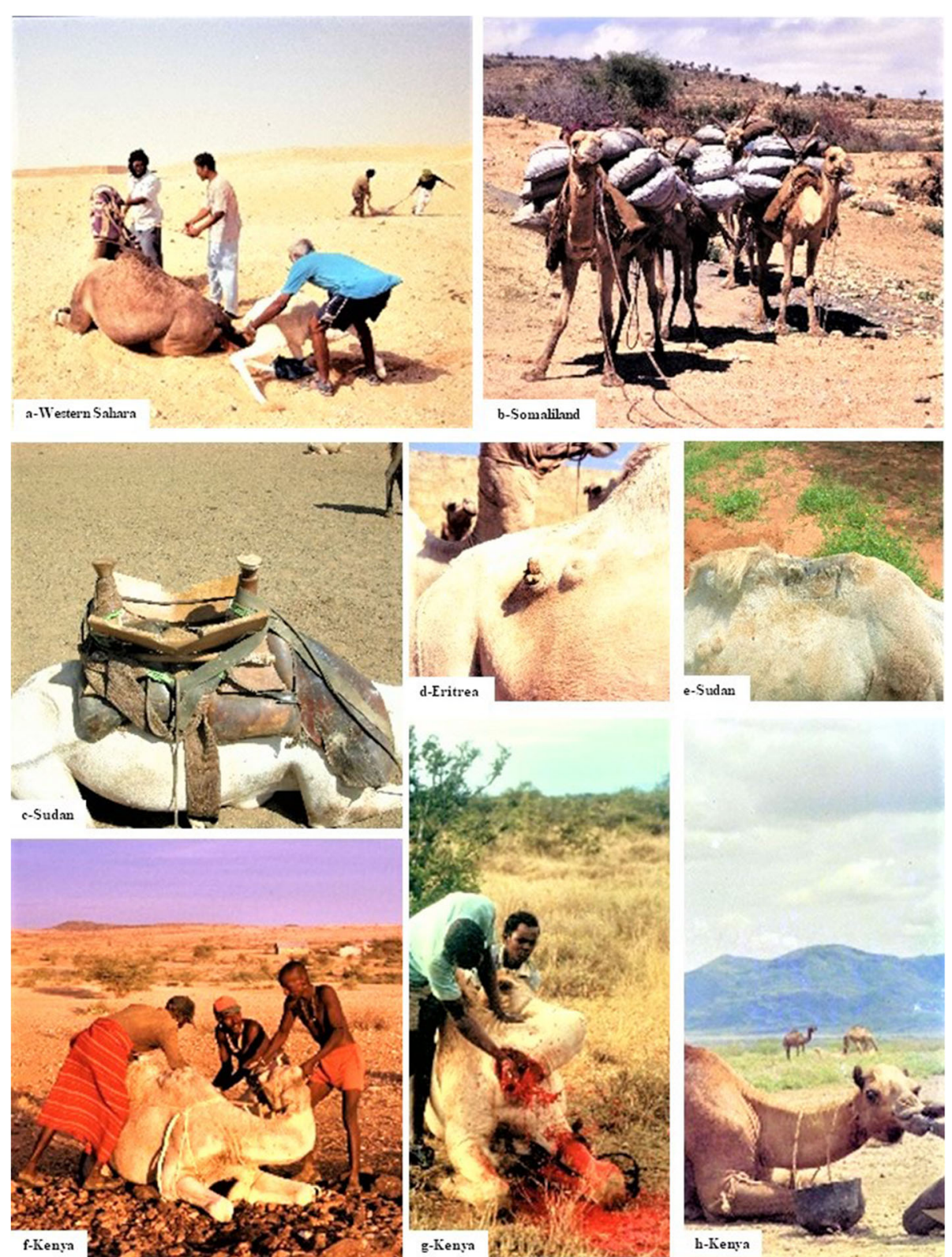

Fig. 10 Images of calf adoption, packing, riding, and slaughtering practices used by nomadic camel pastoralists in a variety of countries (Dioli 2012,2013, Schwartz and Dioli 1992). a Western Sahara. b Somaliland. c, e Sudan. d Eritrea. f-h Kenya

performance of dromedaries relies largely on the practices adopted during colonial times by various military armies. Riding dromedaries used by Egyptian, Pakistani, Indian, Sudanese and Australian Camel Corps were reported to carry an average of $160 \mathrm{~kg}$ for distances varying from 40 to $65 \mathrm{~km} /$ day for several days consecutively (Wilson 1984, Bakht Baidar et al. 2003). Exceptional performances with dromedary capable of being ridden for $130 \mathrm{~km}$ in 1 day, $220 \mathrm{~km}$ in 2 days or $640 \mathrm{~km}$ in 4 days were reported (Gauthier-Pilters and Dagg 1981, Leese 1927). Pack dromedaries are commonly used for journeys of $30-60 \mathrm{~km}$ daily interrupted by few hours of rest, with load weights varying from $108-113 \mathrm{~kg}$ for light body weight dromedaries $(450 \mathrm{~kg} \mathrm{bw})$ to $175-200 \mathrm{~kg}$ or $300-430 \mathrm{~kg}$ for heavier body type dromedaries (550-600 kg bw) (HMSO 1956, Plassio 1912, Droandi 1936, Great Britain War Office 1913, Gleichen 1888, Moore 1921, Marsh 1856, Leonard 1894, Leitch 1940).

\section{Welfare considerations on packing and riding practices}

The most common welfare issue in riding and packing dromedaries is the development of pressure sores, particularly in body areas where the skin is directly covering bony prominences such as the withers and the 
transverse lumbar processes (Fig. 10d, e). The most frequent reasons for the development of saddle sores are the incorrect use of insufficiently padded saddles, nonsymmetrical load placement and the excessive weight of the load and/or the prolonged riding/carrying activity. At present, there are no rational criteria to determine the loading capacity limits of the dromedary with respect to animal welfare. The limits of a riding/packing load and of daily distance that can be covered by dromedaries are heavily influenced by the breed type, body weight, age of the animals and importantly by the terrain and the availability of grazing on the route. Comparisons may be made with horses, another livestock used for riding and packing. In horses, a loading capacity limit of $20 \%$ to a maximum of $30 \%$ of their body weight has been scientifically confirmed using accelerometer-based gait analysis associated with measurement of the midway circumference of the third metacarpal bone (Matsuura et al. 2013, Garlinghouse and Burill 1999, Garlinghouse et al. 1999). In the absence of scientific studies indicating loading limits for dromedaries, practical approaches may be adopted. Useful guidelines were mentioned by Bergin regarding the rate of travel $(\mathrm{km} /$ day $)$ versus duration of the travel (days): a higher rate of travel will be associated with a shorter duration of travel (Bergin 1995, 2:3), and overworked dromedaries necessitate prolonged periods of complete rest (Leonard 1894, Bergin 1995). In practice, daily travel of $40-50 \mathrm{~km}$, equivalent to $8-10 \mathrm{~h}$ of work, is the maximum distance that can be sustained for longer periods without injury to the animal. Welfare assessment of excessive utilisation of packing/riding dromedaries may be done by utilising the level of increased physiological parameters such as rectal temperature, heart rate and rate of respiration. However, it is also possible to evaluate the level of exertion of dromedaries by observing the extent and level of sweat patches on the chest and inguinal areas, foaming at the mouth, watery nasal discharge, lacrimation, incoordination and the tendency to couch down as soon as there is a stop (Bhatt et al. 2002, Dharm Pradeep and Tiwari 2005, Roy et al. 1992, Roy and Tiwari 2010).

\section{Review of common slaughter and other practices}

In all pastoral areas, dromedaries are routinely slaughtered for human consumption, although less commonly than small ruminants. Slaughtering is carried out by restraining the animal in a couched position, his neck bent forcibly to the side, then cutting the jugular vein and carotid artery with subsequent exsanguination and death. However, contrary to other livestock species, the blood vessels are not cut at the throat area but at the base of the neck (Fig. 10f, g). Today, this is the accepted method for dromedaries, and the throat cut is only rarely recommended, although in historical times, it was more common (Fig. 11) (Herrmann and Fisher 2004, Qāsim, 1236-1237). Occasionally, among people of nonMuslim faith, camels are also utilised to provide blood as a source of food by piercing the jugular vein with a small sharp arrowhead and collecting a variable but substantial amount of blood (Fig. 10h).

\section{Welfare considerations on slaughter and other practices}

For obvious practical reasons in a nomadic set-up, dromedaries are slaughtered in the field and not in a slaughterhouse. In pastoral areas, effective camel restraint is well practised, and the inhumane practice of severing the Achille tendon to immobilise the camel used in some modern slaughterhouses is never adopted (Guya and Neme 2016, Seid et al. 2017). The overwhelming majority of nomadic camel owners profess the Muslim faith, so slaughtering, although done in "field conditions", is not casual but carried out according to the precise requirements of the Islamic faith specified in the Qur'an and Hadith: Halal slaughter-Arabic for permissible. The Halal slaughtering procedure requires that the animal must be fully conscious, therefore not stunned, at the time of slaughter and be killed by rapidly severing both the carotid arteries and jugular veins with a sharp knife. The absence of stunning prior to slaughtering the animal may raise doubt about such practice and has been a complaint of animal welfare advocates. In this regard, it must be pointed out that the cutting of the carotid arteries and jugular veins causes rapid loss of consciousness due to swift exsanguination and consequent hypoxia of the brain. This method is therefore judged to be humane by the American Medical Veterinary Association guidelines for the human slaughter of animals (AVMA, 2016). Nevertheless, there is a growing general consensus that the cutting of a throat in a conscious animal has a negative effect on animal welfare. To address this concern, an increasing number of facilities adopt a non-lethal or reversible stunning, rendering the animal unconscious and minimising the pain and distress caused by the act of slaughter. The practice of a pre-slaughter reversible or head only, a form of stunning in which the animal is not killed but simply rendered insensible to pain before the throat cut is done, has been accepted by numerous Muslim-majority countries who continue to issue religious rulings (Fatwa) to approve the practice (Fuseini et al. 2016, Nakyinsige et al. 2013, Kadim et al. 2013). In addition, it is worthy to note that the Court of Justice of the EU has ruled on 17 December 2020 that EU member countries could impose nonlethal stunning before the ritual slaughter of animals in order to promote animal welfare, without infringing the rights of religious groups (CJEU 2020). Reversible stunning is also accepted Halal when is done immediately after the throat is cut (Australia: https://kb.rspca.org.au/ 


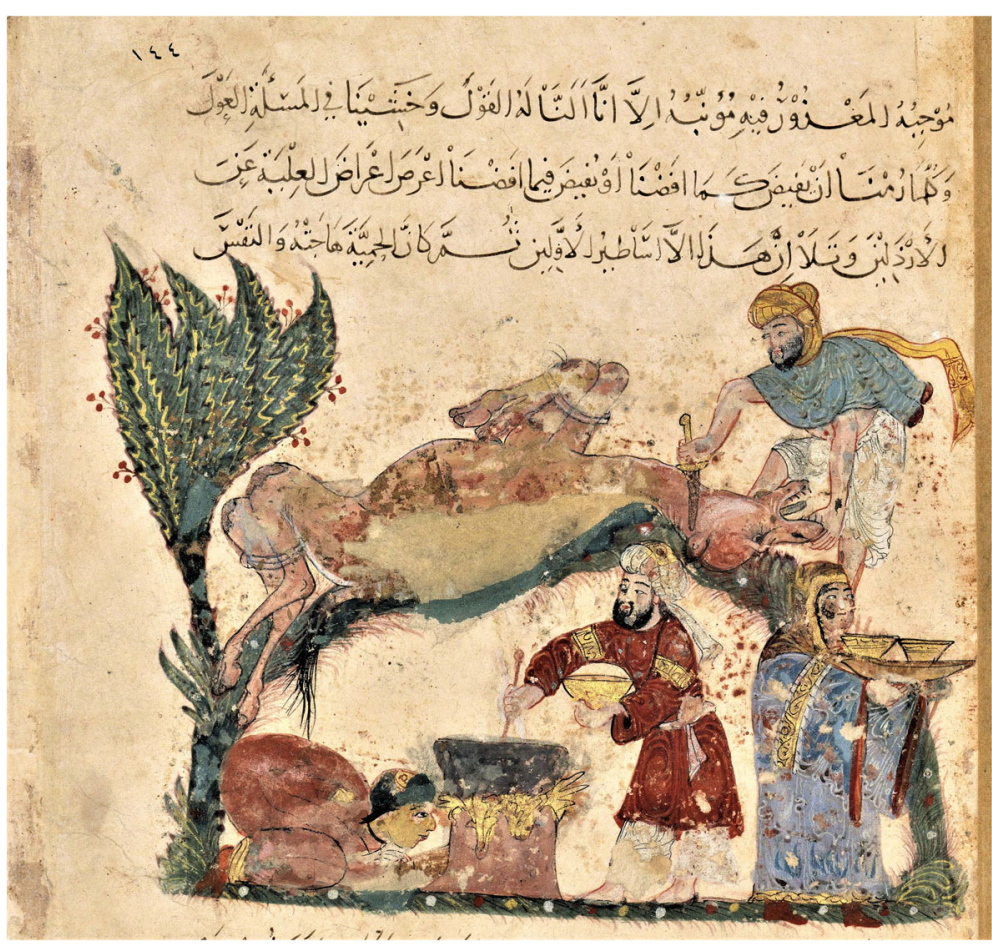

Fig. 11 A page from "The Maqamat al Hariri" date 1236-37 A.D. showing the slaughtering of a dromedary by a cut in the throat area. This is the incorrect way of slaughtering a dromedary. Courtesy of National Library of France. Manuscripts Department. Arab 5847. http://gallica.bnffr/ark:/12148/btv1 b8422965p

knowledge-base/what-is-halal-slaughter-in-australia/) because it has been deemed acceptable by many Muslim religious authorities (Nakyinsige et al. 2013). The use of blood from live dromedaries as a source of food is seldom done among pastoralists being the majority follower of the Islamic faith which prohibits the consumption of blood. When it is done, it may be considered detrimental to the welfare of the animal because it subjects it to a painful procedure that is routinely not performed according to strict hygienic conditions. Blood harvesting from live animals in a pastoral setting may also be done too frequently resulting in anaemia because it rarely follows the general criteria of removing no more than $15-20 \%$ of circulating blood volume, or $1-2 \%$ body weight or 3-6 1 for horses, in any 4-8 weeks period (Anonymous 2009, WHO 2017).

\section{Review of common traditional ethnoveterinary treatments}

Provision of veterinary services in remote pastoral areas is challenging, often consisting only of annual vaccinations. Clinical interventions utilising modern drugs are seldom available. To address this problem, a rich and complex array of ethnoveterinary treatments and husbandry practices have been developed over the course of thousands of years to treat a variety of livestock pathologies (Schillhorn van Veen 1997). Plant-based bioproducts are widely utilised for the treatment of a variety of livestock ailments (Abbas et al. 2002, Basheir et al. 2012, Catley and Mohammed 1996, Davis et al. 1995, Gupta et al. 2015, Kletter et al. 2008, Köhler-Rollefson et al. 2001, McCorkle and MathiasMundy 1992, Raziq et al. 2010, Volpato et al. 2005, Volpato and Puri 2014). However, equally if not more widespread is the practice of burning the skin over certain areas of the animal body with hot irons (Fig. 12a). Branding, firing or thermocautery is used to treat a myriad of pathologies from respiratory infection (Fig. 12b) and musculoskeletal problems (Fig. 12c-g) to traumatic wounds (Fig. 12h) and congenital conditions like goitre (Fig. 13a) (Abdelhadi et al. 2011, Agab 1998, Catley and Mohammed 1996, Gebreyesus et al. 2014, Mathan-Kumar et al. 2012, Namanda 1998, Volpato and Howard 2014, Volpato et al. 2005). In addition to these uses, branding is the preferred method of marking for ownership and tribal affiliations (Fig. 13b) (Landais 2001, MacMichael 1913, Ohta 1987, Waddington 1974) and for aesthetic modifications (Fig. 13c) (Dioli 2018). Other ethnoveterinary treatments commonly carried out among pastoralists are bone setting although essentially only for calves (Fig. 13d, e) and "bloodletting" to treat swollen areas, chronic diseases or infertility problems (Fig. 13f, g) (Antoine-Moussiaux et al. 2007, McCorkle and Martin 1998, Namanda 1998, Seele 2017, Abbas 1997, Abbas et al. 2002, ElMahi and ElMahi 2014, Schwabe 

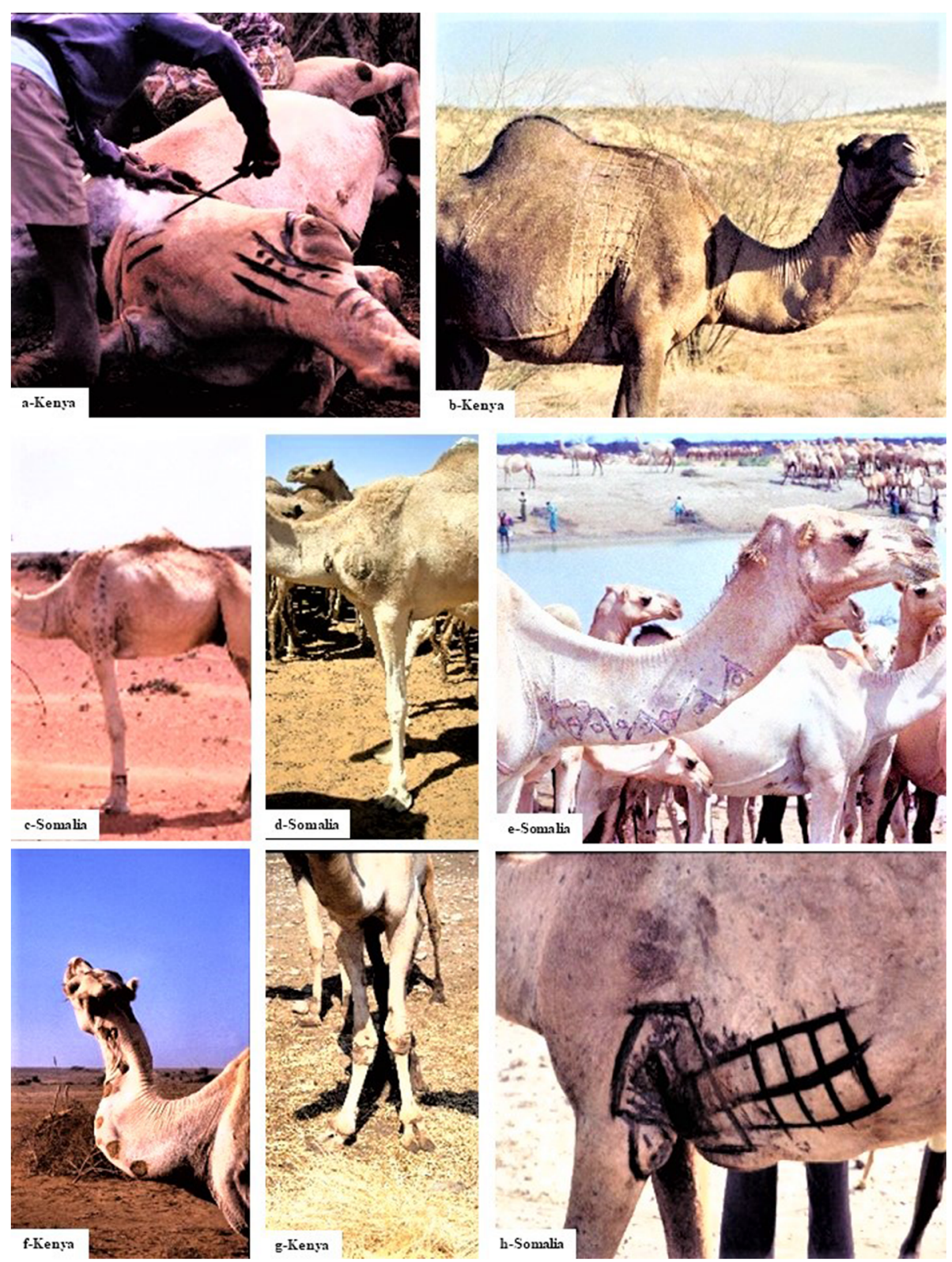

Fig. 12 Images of various ethnoveterinary treatments used by nomadic camel pastoralists in a variety of countries (Dioli 2012,2013, Schwartz and Dioli 1992). a, b, f, g Kenya. c-e, h Somalia. f, g Kenya

and Kuojok 1981). Radical treatments are occasionally carried out to remove necrotic body areas. A common one is in the area around the nostrils where massive infestations of the nose tick Hyalomma dromedarii often damage the tissue so severely to cause gangrene (Fig. 14a) (Dioli et al. 2001). In some areas of western Africa, Mauritania, a sliver of skin is removed as a form of tribal/ownership marking. Castration is regularly carried out by restraining the animal on the side, cutting the scrotum and manually removing the testis by cutting all tissues and blood vessels without any form of ligature to control haemorrhages (Fig. 14b, c).

\section{Welfare considerations on traditional ethnoveterinary} treatments

The use of plants instead of allopathic medicines does not represent a welfare issue except perhaps when using excessively forceful administration methods. The practice of branding/firing/thermocautery as a treatment for pathological conditions should be considered a detrimental practice because it is undoubtedly painful and causes very visible injury to the animal. In addition, the practice is unnecessary because it has not been proven effective to treat acute or chronic musculotendon injuries (Silver et al. 1983). Various veterinary associations 

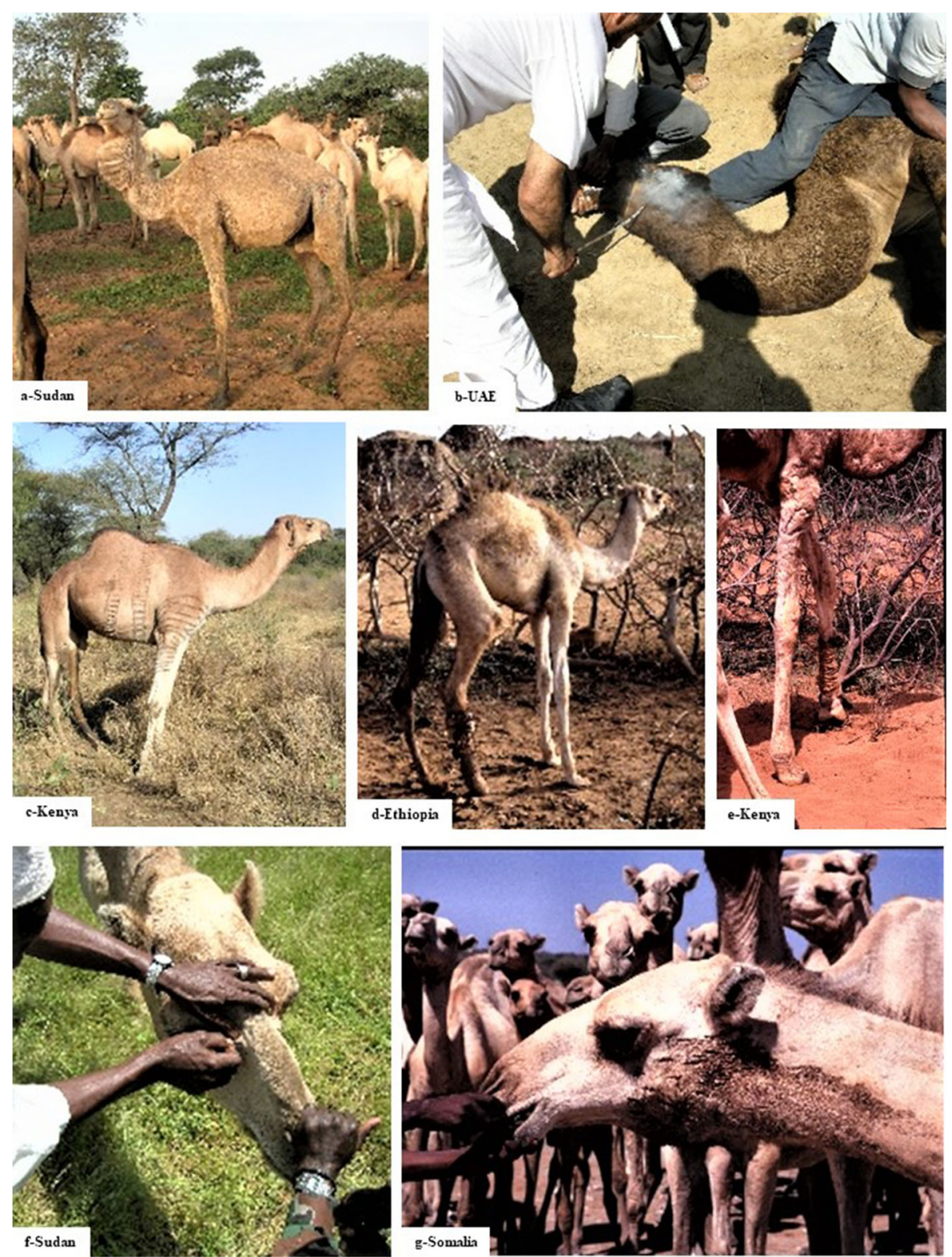

Fig. 13 Images of various ethnoveterinary treatments used by nomadic camel pastoralists in a variety of countries (Dioli 2012,2013, Schwartz and Dioli 1992). a, f Sudan. b UAE. c, e Kenya. d Ethiopia. f Sudan. g Somalia

worldwide such as the American Association Equine Practitioners (AAEP), the Canadian Veterinary Medical Association (CVMA), the Royal College Veterinary Surgeons (RCVS, UK) and the Australian Veterinary Association (AVA) to mention a few, no longer support the use of thermocautery (Anonymous 2013, 2020, Jepson 2012). Australia bans horses that have had a thermocautery procedure from competitions (Anonymous 2021). The increasing consensus is that firing is unethical and should be banned on welfare grounds (Jepson 2012, Harris 2012). In some countries, such as the UK, the procedure may be a violation of the Animal Welfare
Act 2006 (Anonymous 2011) or in Australia listed as a "prohibited procedure" (POCTA Act 2020). Branding as a form of establishing ownership as is often done in cattle is tolerated. However, concern is growing about its impact on animal welfare, and it is increasingly discouraged or recommended to be used together with pain relief therapy because of pain and distress for the animal (AVMA 2011, NFACC 2013, New Zealand Government 2018a). The consensus regarding surgical castration is that as a surgical procedure, it induces pain and physiological stress in animals of all ages. Legislation exists in many 


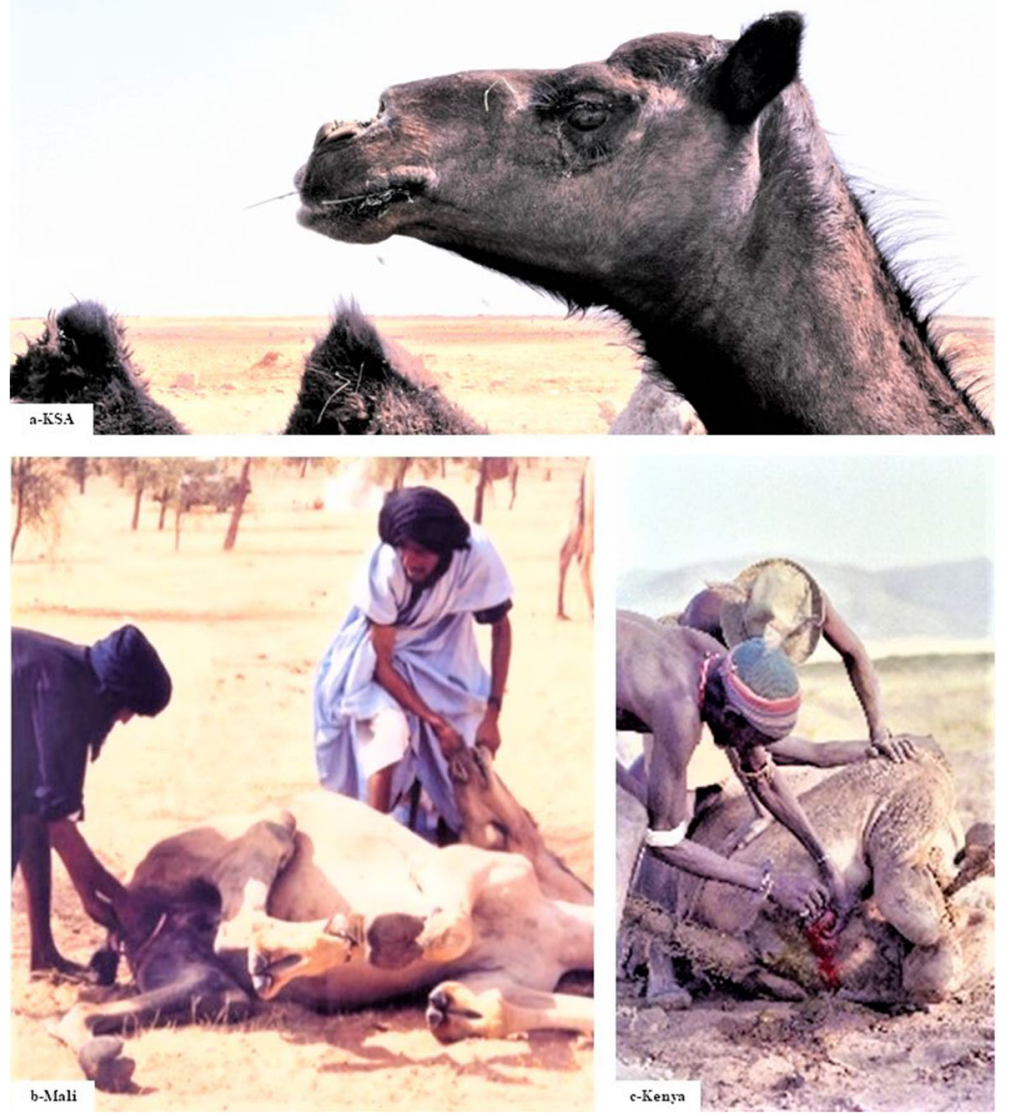

Fig. 14 Images of various ethnoveterinary treatments used by nomadic camel pastoralists in a variety of countries (Dioli 2012,2013, Schwartz and Dioli 1992). a KSA. b Mali. c Kenya

countries strictly regulating animal surgical procedures such as the UK Animal Welfare Act (2006) requiring that castration be done with appropriate use of anaesthesia and analgesia so that pain and stress are minimised (AVMA 2014, New Zealand Government 2018b).

\section{Discussion and reflections on pastoralism and livestock welfare issues}

There is no doubt that animal welfare is a fundamental part of any livestock production system. However, the livestock welfare assessment protocols have been developed for intensive or farm-based livestock production systems and cannot be used to evaluate welfare issues for extensively managed livestock (Kaurivi et al. 2020). An understanding of the livestock husbandry practices adopted by pastoralists to survive and thrive in arid ecosystems is a prerequisite to a realistic assessment of the welfare of dromedaries kept in such environments. The
Five Freedoms paradigm expressed by the Farm Animal Welfare Council must therefore be put in the perspective of livestock raised in arid environments under nomadic management. Specifically, the author believes that the following reflections on the "Five Freedoms" should be considered:

- Freedom from hunger and thirst must take into consideration that dromedaries are kept in ecosystems dominated by a severe fluctuation of available forage and feed, and droughts are a common occurrence. Dromedaries are therefore routinely and "naturally" exposed to food scarcity, and such welfare issues can only be partially addressed or not at all by nomadic pastoralists. Dromedaries are capable of tolerating thirst and are exposed to it not because of cruelty but as a grazing management tool to take advantage of pristine 
grazing areas far from permanent watering points (which are usually overgrazed). During the challenge of the dry season in pastoral areas, dromedaries are routinely trained to tolerate water deprivation of 10-12 days or even up to 30 days. In these times, they will graze on fluid-rich but unpalatable plants such as bitter apple (Colocynthis citrullus). While admitting that nutrition deficiencies may occur in a pastoral setting, it must also be admitted that the modern provision of abundant and correct nutritional fodder does not automatically equate to good welfare (Manteca et al. 2008, Mattiello et al. 2019). Nutritional difficulties commonly occurring in arid pastoral areas are balanced by the positive reality that free-range dromedaries can express their own normal behaviour by choosing their preferred food and using pleasurable environmental exploration activities. Hunger/malnourishment issues are frequently a reality for male dromedary calves because, being less valued than female calves, they receive less of their mother's milk because the majority is taken for human consumption. This welfare issue must be put in the correct perspective: human survival has obvious a precedence over calf survival.

- Freedom of discomfort must be put in context. It is implicit that the husbandry system required by nomadic livestock keepers cannot adopt permanent livestock enclosures. The only enclosures used, but not always, are simply built night corrals that, while protecting against occasional predators, do not offer protection from inclement weather and wind or provide dromedaries with beneficial shaded areas (Zappaterra et al. 2021). The obvious negative element of the lack of proper protection from inclement weather events must be balanced with the awareness that dromedaries are a species that has evolved in desert ecosystems, and their thermal comfort zone is well adapted to tolerate the desert's large daily/seasonal temperature fluctuations and lack of shade.

- Freedom of pain, injuries or disease is a cardinal issue for animal welfare. However, the reality on the ground is that in remote pastoral areas, modern veterinary drugs such as pain-relieving anaesthetic and analgesic as well as effective antimicrobial drugs are seldom, if ever, available. Furthermore, when available, such drugs are often too expensive or improperly stored and used, leading to the widespread development of drug resistance. This situation is unlikely to change in the foreseeable future. Ethnoveterinary practices are therefore the only alternative available even if painful or with uncertain efficacy. The ubiquitousness of many diseases forces nomadic pastoralists to intentionally expose their dromedaries to specific diseases such as trypanosomosis, camel pox and contagious ecthyma in an attempt to build up their immunity (Cauvet 1925, Curasson 1947, Higgins 1983, Köhler-Rollefson et al. 2001, Leese 1927). This practice is not limited to dromedary but is also done for goats against CCPP and for cattle against CBPP (McCorkle and Mathias-Mundy 1992, Gebreyesus et al. 2014). Dromedary lactation is often an essential food item for survival, and so calves, required to maintain a healthy and prolong lactation in their mothers, are often kept alive even in case of painful lesions that would warrant euthanasia.

- Freedom to express normal behaviour is probably a welfare attribute that is likely to be better implemented in a nomadic pastoralism set-up than in the intensive or semi-intensive systems. Dromedaries kept by nomadic pastoralists are free-range, so they have unlimited space to move at will and are able to fully interact with the environment and with other herd animals. While positive, it must be accepted that these aspects may also pose management and care challenges to rapidly address eventual suffering and illness (Vaarst and Kristensen 2000). It should be noted as an important positive aspect of the pastoral nomadic system: the more natural mother-calf relationship. Dromedary newborn calves are freely allowed to suckle their dam at will in the first 2-3 months of their life, and afterwards, they remain in close contact with their mother until their weaning age at 12-18 months. Males in rut are still limited in their freedom even in the nomadic pastoral set-up; however, this situation is limited to their rutting period, and when it is finished, they rejoin the main herd. This does not happen in intensive/semi-intensive dromedary farms where breeding males are kept in separate individual paddocks.

- Freedom from fear and distress is difficult to objectively evaluate in a nomadic pastoral set-up. The reality of ensuring human survival in a harsh ecosystem has shaped many of the dromedary husbandry practices, and the ones causing fear and distress should be judged as necessary practices evolved over thousands of years of dromedary keeping. While the practices may be judged not to be welfare friendly, time and local experience have proven them to be the most effective in achieving the desired objectives. Claiming that such practices are a form of gratuitous cruelty fails to acknowledge that the dromedary in almost all pastoral societies is given special respect because it is considered Allah's gift to mankind and is mentioned in the Holy Qur'an (Khalaf 2000). Dromedaries among pastoralists are not simply livestock but the emblem of a myriad of virtues. They are the subjects of a multitude of 
poems, proverbs, songs, metaphors and tales of wisdom of many camel pastoralist cultures all over the world from West Africa to the Horn of Africa and the Arabian Peninsula (Balehegn 2016, Kurpershoek 1994, Morin 1996, Pinto Cebrián, 1997, Sowayan 1985, Xange and Abokar 1987).

Most of the modern welfare assessment schemes for ruminants are heavily focused on the absence of negative welfare conditions. However, it is more and more obvious that the absence of negative welfare conditions does not necessarily mean that animals are in good welfare and have a good quality of life (Mattiello et al., 2019). The equivalence of good welfare with an absence of illness is incomplete. Good welfare should also include the possibility for livestock to live a life in which they have opportunities to express their natural behaviour and have freedom of choice and abundant space available (Alrøe et al. 2001, Vaarst and Kristensen 2000). On this basis, it may be stated that the welfare of dromedaries in pastoral livestock systems is probably better than the welfare of dromedaries reared in intensive and semiintensive systems. By allowing their animals' constant access to outdoor areas and a greater freedom of behaviour to express their individual preferences, nomadic pastoral livestock systems might be compared to a form of organic agriculture (Vaarst and Alrøe 2012). Husbandry practices in pastoral areas are part of a cultural and ecological system that has been developed over thousands of years. Such a close relationship has resulted in the modification of the biology and behaviour of domestic livestock species as well as profoundly influencing regional cultures and human standard of living. It is more appropriate to define it as a coevolution because it has also modified the human genome (Holden and Mace 2009, Lund and Olsson 2006). Animal welfare issues are undoubtedly present but should be put in perspective. As in the case of organic farming "organic values may also call for sacrifice of individual welfare in a conventional sense... Whether this is good or bad cannot be decided without entering into an inquiry and discussion of the values and ethics involved" (Alrøe et al. 2001: 1). As stated by Simonsen, living a natural life does not imply the best welfare in terms of the sum of positive and negative experiences (Simonsen 1996: 91-96 quoted by Alrøe et al. 2001: 12), and therefore, positive or negative judgements of what is acceptable or unacceptable are becoming an ethical question (Ministry of Agriculture and Fisheries, 1995: 23-24).

\section{Conclusions}

Animal welfare is undoubtedly a complex subject to define because mankind has many specific cultural, historical, religious values, beliefs and norms regulating human attitude and treatment towards livestock (Serpell 2004). Issues such as "product sale price" and "preservation of local cultural landscape" and even "folk's conceptions of animal welfare" may influence the evaluation of animal welfare practices and attitudes to such an extent that they cannot be applicable to all livestock production systems and regions of the world (Bruckner 2019, Kaurivi et al. 2019, Zander and Hamm 2010). An added element of complexity in reaching a universally correct definition of animal welfare involves the weight of personal opinions. A scientist may define it according to his own ethical position and concept of animal welfare. The consequence is that diametrically opposite conclusions may be reached on the welfare of the same group of animals (Fraser et al. 1997). It would therefore make sense that animal welfare concepts of "non-specialists", in this case, nomadic pastoralists, be considered because their ethical values are uniquely attuned to their environment (Weary and Robbins 2019). In judging animal welfare in pastoral areas, it may be more pragmatic to adopt Frey's approach of "moral intuition": "The relationship of morals to common sense, meaning that "animal life is less valuable than human life" (Frey 1988: 192), and while cruelty to animals should be opposed, we should not assume that the life of animals and humans have the same value. Humans and livestock should be seen as part of an ecological system in which human interests and values have a priority over animal interest (Stenmark 2002: 90-91), and any unavoidable negative animal experiences should be perceived as a natural part of life, a "functional feedback system connecting individual behaviour and the surrounding world" (Lund et al. 2004) that can never be completely deleted from the animal's range of experience (Alrøe et al. 2001, Lund and Röcklinsberg, 2001). Nomadic husbandry practices have evolved over thousands of years, successfully achieving and maintaining livestock production in incredibly harsh and hostile ecosystems. Criticism of animal welfare practices among nomadic pastoralists should be balanced by the acknowledgement that such practices, while deemed cruel, have been the ones responsible for guaranteeing human survival in unforgiving ecosystems.

\section{Acknowledgements \\ My personal thanks to His Highness Sheikh Mohammed bin Hamad bin Mohammed Al Sharqi, the Crown Prince of Fujairah, for generously promoting and supporting camel research. A sincere thanks to Dr. Barbara Walsh for editing the manuscript's English.}

Author's contributions

The manuscript conceptualisation, data collection, analysis and writing were done by the author. The author read and approved the final manuscript.

Funding

Not applicable. 


\section{Availability of data and materials}

All data are obtainable from the reference list. Photographs are available from the author or in the quoted Open Access websites.

\section{Declarations}

Ethics approval and consent to participate

Not applicable.

\section{Consent for publication}

Not applicable.

\section{Competing interests}

The author declares that he has no competing interests.

\section{Received: 7 April 2021 Accepted: 21 October 2021}

Published online: 17 February 2022

\section{References}

Abbas, B. 1997. Ethnoveterinary practices of camel pastoralists in Butana, northeastern Sudan. In DHP Publications Series No 4. Addis Abba: Ethiopia.

Abbas, B., A.A. Al-Qarawi, and A. Al-Hawas. 2002. The ethnoveterinary knowledge and practice of traditional healers in Qassim Region, Saudi Arabia. Journal of Arid Environments 50 (3): 367-379. https://doi.org/10.1006/jare.2001.0904.

Abdelhadi, O., S. Babiker, M. Elemam, and B. Faye. 2011. Husbandry practices of EL-Kababish camel herders: Case study north Kordofan state, Sudan. Journal of Camel Practice and Research 18: 7-14.

Agab, H. 1998. Traditional treatment methods of camel in Eastern Sudan with emphasis on firing. Journal Camel Practice and Research 5: 161-164.

Al Ani, F.K. 2004a. Camel management and diseases. Amman: Dar Ammar Book Publishing; 455 pp.

Al Ani, F. K. 2004b. Camel management and husbandry. In Al Ani F. K. Camel management and diseases. Amman: Dar Ammar Book Publishing; pp 69-90.

Alrøe, H.F., M. Vaarst, and E.S. Kristensen. 2001. Does organic farming face distinctive livestock welfare issues? A conceptual analysis. Journal of Agricultural and Environmental Ethics 14 (3): 275-299. https://doi.org/10.1 023/A:1012214317970.

Anonymous. 2009. Guidelines for the welfare of livestock from which blood is harvested for commercial and research purposes, National Animal Ethics Advisory Committee (NAEAC)c/o MAF Biosecurity New Zealand. Available at: https:/www.mpi.govt.nz/animals/animal-welfare/national-animal-ethics-a dvisory-committee/naeac-publications/. Accessed 6 Nov 2020.

Anonymous. 2011. Firing of horses, RCVS News. p 10. Available at: https://www. rcvs.org.uk/news-and-views/publications/rcvs-news-november-2011/

Anonymous. 2013. National Farm Animal Care Council. The code of practice for the care and handling of equines. Section 4.4 Lameness 33. Equine Canada Ottawa,. Available at: https://www.nfacc.ca/pdfs/codes/equine_code_of_pra ctice.pdf

Anonymous. 2020. American Association Equine Practitioner 2020 Leadership Resource Guide, Ethical and Professional Guidelines, 4033 Iron Works Parkway, Lexington, KY 40511. Available at: https:/aaep.org/sites/default/files/ Documents/2020_Resource_Guide_.pdf

Anonymous. 2021. Australian rules of racing. As at 1 January 2021. Including amendments to AR 122. Racing Australia. Available at: https://www.racinga ustralia.horse/uploadimg/Australian_rules_of_Racing/Australian_Rules_of_Ra cing_01_January_2021.pdf

Antoine-Moussiaux, N., B. Faye, and G. Vias. 2007. Tuareg ethnoveterinary treatments of camel diseases in Agadez area (Niger). Tropical Animal Health and Production 39 (2): 83-89. https://doi.org/10.1007/s11250-007-4404-1.

AVMA. 2011. Literature review on the welfare implications of hot-iron branding and its alternatives (April 4, 2011). Available at: https://www.avma.org/sites/defa ult/files/resources/hot-iron_branding_bgnd.pdf

AVMA. 2014. Literature review on the welfare implications of castration of cattle. American Veterinary Medical Association. Available at: https://www.avma.org/ KB/Resources/LiteratureReviews/Documents/castration-cattlebgnd.pdf

AVMA. 2016. AVMA guidelines for the humane slaughter of animals: 2016 edition. Available at https://www.avma.org/sites/default/files/resources/Humane-Sla ughter-Guidelines.pdf. Accessed 6 Nov 2020.

Baidar, Khan, A. labal, and M. Riaz. 2003. Production and management of camels. Faisalabad: Department of Livestock Management, University of Agriculture.
Balehegn, M. 2016. Ecological and social wisdom in camel praise poetry sung by Afar Nomads of Ethiopia. Journal of Ethnobiology 36 (2): 457-472. https://doi. org/10.2993/0278-0771-36.2.457.

Basheir, O., B.K.H. Elmalik, A.E. Abdelgadir, and A.A.R. Gameel. 2012. Traditional and modern practices in the diagnosis, treatment and prevention of animal diseases in South Kordofan State, Sudan. Journal of Cell and Animal Biology 6 (15): 213-225. https://doi.org/10.5897/jcab11.066.

Bergin, T. J., 1995. Camels as a source of energy. In Evans, J. O., S. P. Simpkin, D. J. Atkins, Camel Keeping in Kenya, Ministry of Agriculture, Livestock Development and Marketing, Chapter 2(1): 1-10.

Bhatt, Y.C., R. N. Verma and A. K. Sharma. 2002. Draught ability assessment of Indian camels through a fatigue analysis. Draught Animal News No. 36, Centre for Tropical Veterinary Medicine University of Edinburgh, pp18-24

Broom, D.M. 1991. Animal welfare: concepts and measurement. Journal of Animal Science 69 (10): 4167-4175, https://doi.org/10.2527/1991.69104167x.

Bruckner, D.W. 2019. Philosophy and animal welfare science. Philosophy Compass 14 (10): e12626. https://doi.org/10.1111/phc3.12626.

Catley, A., and A.A. Mohammed. 1996. Ethnoveterinary knowledge in Sanaag Region, Somaliland (Part II): Notes on local methods of treating and preventing livestock disease. Nomadic Peoples 39: 135-146.

Cauvet, G. 1925. Le Chameau (anatomie, physiologie, races extérieur, alimentation, maladies, role économique), 947. Paris: Librairie J. B. Bailliere et Fils.

CJEU. 2020. In order to promote animal welfare in the context of ritual slaughter, member states may, without infringing the fundamental rights enshrined in the charter, require a reversible stunning procedure which cannot result in the animal's death. Court of Justice of the European Union, Press Release No 163/20, Luxembourg, 17 December 2020, Judgment in Case C-336/19. Available at: https://curia.europa.eu/jcms/upload/docs/application/pdf/202 0-12/cp200163en.pdf.

Curasson, G. 1947. Le Chameau et ses maladies, 462. Paris: Vigot.

Davis, D.K., K. Quraishi, D. Sherman, A. Sollod, and C. Stem. 1995. Ethnoveterinary medicine in Afghanistan: An overview of indigenous animal health care among Pashtun Koochi nomads. Journal of Arid Environments 31 (4): 483-500 https://doi.org/10.1016/s0140-1963(05)80131-4.

Dioli, M. 2012. The traditional management of the one-humped camel (Camelus dromedarius) in the Horn of Africa: Milking, fostering and weaning techniques. In Camels in Asia and North Africa. Interdisciplinary perspectives on their past and present significance, ed. E.M. Knoll and P. Burger, 199-207. Austrian Academy of Sciences Press https://austriaca.at/0xc1aa5576\%200×002 d244f.pdf.

Dioli, M. 2013. Pictorial Guide to Traditional Management, Husbandry and Diseases of the One-Humped Camel Dioli M. web based: https://www. google.com/books/edition/Pictorial_Guide_to_Traditional_Managemen/sZA bOhTtBgkC?hl=en\&gbpv=0

Dioli, M. 2018. Nomad aesthetic: Cattle modifications among the northern Turkana of north west Kenya. Pastoralism. Research, Policy and Practice 8 (1): 6. https://doi.org/10.1186/s13570-017-0110-4.

Dioli, M. 2020. Dromedary (Camelus dromedarius) and Bactrian camel (Camelus bactrianus) crossbreeding husbandry practices in Turkey and Kazakhstan. An in-depth review. Pastoralism. Research, Policy and Practice 10: 6 https://doi. org/10.1186/s13570-020-0159-3.

Dioli, M., S. Jean-Baptiste, and M. Fox. 2001. Ticks (Acari: Ixodidae) of the one-humped camel (Camelus dromedarius) in Kenya and southern Ethiopia: Species composition, attachment sites, sex ratio and seasonal incidence. Revue d'Elevage et de Médecine vétérinaire des Pays tropicaux 54 (2): 115-122.

Droandi, I. 1936. II cammello: storia naturale, anatomica, fisiologica, zootecnica, patologia. Firenze: Instituto Agricolo Coloniale Italiano.

Dupire, M. 1962. Peuls nomades: Etude descriptive des Wodaabe nomades du sahel nigerien. Travaux et Mémoires de l'Institut d'Ethnologie 64: 327.

El Mahi, A.T., and Y.A.T. ElMahi. 2014. Traditional camel veterinary treatment among the Bedouins of Sultanate of Oman: A case of recurrent miscarriages. Journal of Agricultural and Marine Sciences 19: 71-74.

Evans-Pritchard, E. E. 1937. Economic life of the Nuer: Cattle. Sudan Notes and Records 20, no. 2-209-45. http://www.jstor.org/stable/41716262. Accessed 15 Dec 2020.

FAOSTAT. 2020. Food and Agriculture Organization. Rome: Food and agriculture data. Available at: http://www.fao.org/faostat/. Accessed 25 Nov 2020.

Farm Animal Welfare Council, 2012. Farm Animal Welfare Council: Five freedoms. UK: Farm Animal Welfare Council. Available at https://is.gd/Ajl7UT. Accessed Feb 2021. 
Fawi Nahid M.T., M. A. Ahmed Hadeel. 2017. Creating Sustainable Food Markets (A Case Study of Urban Consumers' Camel Milk Consumption in Khartoum Sudan). Journal of Veterinary Medicine and Animal Production 7 (1).

Faye, B. 2020. How many large camelids in the world? A synthetic analysis of the world camel demographic changes. Pastoralism; Research, policy and practice 10 (1): 25. https://doi.org/10.1186/s13570-020-00176-z.

Ferguson, J.K.W. 1941. A study of the motility of the intact uterus at term. Surgery, Gynecology and Obstetrics 73: 359-366.

Fraser, D. 2008. Understanding animal welfare. Acta Veterinaria Scandinavica 50 (S1): S1. https://doi.org/10.1186/1751-0147-50-S1-S1.

Fraser, D., D.M. Weary, E.A. Pajor, and B.N. Milligan. 1997. A scientific conception of animal welfare that reflects ethical concerns. Animal Welfare 6: 187-205 Available at: https://www.wellbeingintlstudiesrepository.org/cgi/viewcontent. cgi?article $=1000 \&$ context $=$ ethawel.

Frey, R.G. 1988. Moral standing, the value of lives, and speciesism. Between Species. 4 (3): 191-201 https://doi.org/10.15368/bts.1988v4n3.8.

Fuseini, A., T.G. Knowles, P.J. Hadley, and S.B. Wotton. 2016. Halal stunning and slaughter: Criteria for the assessment of dead animals. Meat Science 119: 132 137. https://doi.org/10.1016/j.meatsci.2016.04.033.

Garlinghouse S. E., R. E. Bray, E. A. Cogger, and S. J. Wickler. 1999. The influence of body measurements and condition score on performance results during the 1998 Tevis Cup. Proceedings 16th Equine Nutrition and Physiology Society Symposium, North Carolina. 398-402.

Garlinghouse, S.E., and M.J. Burill. 1999. Relationship of body condition score to completion rate during $160 \mathrm{~km}$ endurance races. Equine Veterinary Journal 30 (Suppl): 591-595.

Gauthier-Pilters, H., and A.I. Dagg. 1981. The camel. Its evolution, ecology, behavior and relationship to man. Chicago: The University of Chicago Press.

Gebreyesus, G., A. Haile, and T. Dessie. 2014. Ethno-veterinary knowledge and practices of Issa-Somali pastoralists around Dire Dawa, Eastern Ethiopia. International Journal of Research and Reviews in Pharmacy and Applied Sciences 4: 910-921 http://ijrrpas.com/article/ethno-veterinary-knowledge-a nd-practices-issa-somali-pastoralists-around-dire-dawa-eastern.

Gleichen, E. 1888. With the camel corps up the Nile. London: Chapman and Hall.

Great Britain War Office, 1913. Camel corps training, Provisional. Regulations for the Equipment of the Army. Part 2, Section XV: Camel Corps School, Egypt.

Gupta, L., G. Tiwari, and R. Garg. 2015. Documentation of ethnoveterinary remedies of camel diseases in Rajasthan, India. Indian Journal of Traditional Knowledge 14 (3): 447-453.

Guya, M.E., and G. Neme. 2016. Camel slaughtering practices and meat production in Eastern Ethiopia. Science, Technology and Arts Research Journal 4 (3): 123-128. https://doi.org/10.4314/star.v4i3.19.

Harris, G. 2012. Ethics of firing debated at BEVA congress. Veterinary Record 171 (13): 312-314. https://doi.org/10.1136/vr.e6500.

Herrmann, K., and A. Fisher. 2004. Method for hygienic slaughter of camels, 7: 89108. In Milk and meat from the camel: Handbook on products and processing, ed. Z. Farah, A. Fisher, A.G. vdf-Hochschulverlag, and an der ETH Zurich.

Higgins, A.J. 1983. Observations on the diseases of the Arabian camel (Camelus dromedarius) and their control: A review. Veterinary Bulletin 53 (12): 10891099.

Her Majesty's Stationery Office. 1956. In animal management, 286. London: Her Majesty's Stationary Office.

Holden, C., and R. Mace. 2009. Phylogenetic analysis of the evolution of lactose digestion in adults. Human Biology 81 (5-6): 597-619. https://doi.org/10.3378/ 027.081.0609.

Imamura, K., R. Salmurzauli, M.K. Iklasov, A. Baibayssov, K. Matsui, and S.T. Nurtazin. 2017. The distribution of the two domestic camel species in Kazakhstan caused by the demand of industrial stockbreeding. Journal of Arid Land Studies 26 (4): 233-236.

Jepson, P. 2012. Firing and thermocautery. In Proceedings of the 51st British Equine Veterinary Association BEVA Congress, September 12-15, 2012 Birmingham, UK, 86.

Kadim, I.T., M.M. Farouk, O. Mahgoub, and A.E. Bekhit. 2013. Slaughtering and processing of camels. In Camel meat and meat products, vol. 5, ed. I.T. Kadim, O. Mahgoub, B. Faye, M.M. Farouk. Cambridge: CABI, 54-72.

Kaurivi, Y.B., R. Laven, R. Hickson, T. Parkinson, and K. Stafford. 2020. Developing an animal welfare assessment protocol for cows in extensive beef cow-calf systems in New Zealand. Part 1: Assessing the feasibility of identified animal welfare assessment measures. Animals 10 (9): 1597. https://doi.org/10.3390/a ni10091597.
Kaurivi, Y.B., R. Laven, R. Hickson, K. Stafford, and T. Parkinson. 2019. Identification of suitable animal welfare assessment measures for extensive beef systems in New Zealand. Agriculture 9 (3): 66. https://doi.org/10.3390/agriculture9030066.

Khalaf, S. 2000. Poetics and politics of newly invented traditions in the gulf: Camel racing in the United Arab Emirates. Ethnology 39 (3): 243-261. https:// doi.org/10.2307/3774109.

Kletter, C., S. Glasl, T. Thalhammer, and S. Narantuya. 2008. Traditional Mongolian medicine - A potential for drug discovery. Scientia Pharmaceutica 76 (1): 4963 https://doi.org/10.3797/scipharm.0802-04.

Köhler-Rollefson, I., P. Mundy, and E. Mathias. 2001. A field manual of camel diseases: Traditional and modern health care for the dromedary, 272. London, UK: ITDG Publishing. https://doi.org/10.3362/9781780441153.

Kolb, P. 1719. Caput Bonae Spei hodiernum, that is: a complete description of the African prelude to the Good Hope: which is dealt with in three parts, how it looks today, according to its situation and characteristics .... Nürnberg, Monath.

Kuria, S.G., O.K. Koech, A.O. Adongo, S. Murithi, J.T. Njoka, and P. Kamande. 2016. Cost of production, marketing and revenue generation from Somali camel breed in Isiolo and Marsabit counties of northern Kenya. Livestock Research for Rural Development 28: 229 Available at: http://www.lrrd.org//rrd28/12/kuri2 8229.html, Accessed 6 Nov 2020.

Kurpershoek, P.M. 1994. Oral poetry and narratives from Central Arabia, volume 1: The poetry of ad-Dindān, A Bedouin bard in Southern Najd, Leiden, E. J. Brill, 368.

Landais, E. 2001. The marking of livestock in traditional pastoral societies. Revue scientifique et technique (International Office of Epizootics) 20 (2): 463-479. https://doi.org/10.20506/rst.20.2.1286.

Le Quellec, J.L. 2011. Provoking lactation by the insufflation technique as documented by the rock images of the Sahara. Anthropozoologica 46 (1): $65-$ 125 https://doi.org/10.5252/az2011n1a4.

Leese, A.S. 1927. A treatise on the one-humped camel in health and in disease. Stamford: Haynes and Son.

Leitch, I. 1940. The feeding of camels.Aberdeen: Imperial (subsequently Commonwealth) Bureau of Animal Nutrition, UK; No. 13, 35.

Leonard, A.G. 1894. The camel, its uses and management. London: Longmans, Green, and Co..

Lucas, A.T. 1989. Cattle in ancient Ireland, 315. Kilkenny: Boethius Press.

Lund, V., R. Anthony, and H. Röcklinsberg. 2004. The ethical contract as a tool in organic animal husbandry. Journal of Agricultural and Environmental Ethics 17 (1): 23-49 https://doi.org/10.1023/b:jage.0000010843.60352.65.

Lund, V., and I.A.S. Olsson. 2006. Animal agriculture: Symbiosis, culture, or ethical conflict? Journal of Agricultural and Environmental Ethics 19 (1): 47-56 https:// doi.org/10.1007/s10806-005-4378-9.

Lund, $V_{\text {., }}$ and H. Röcklinsberg. 2001. Outlining a conception of animal welfare for organic farming systems. Journal of Agricultural and Environmental Ethics 14 (4): 391-424. https://doi.org/10.1023/A:1013049601079.

MacMichael, H.A. 1913. Brands used by the chief camel-owning tribes of Kordofán (a supplement to the tribes of Northern and Central Kordofán), 132. Cambridge, University Press.

Manteca, X., J.J. Villalba, S.B. Atwood, L. Dziba, and F.D. Provenza. 2008. Is dietary choice important to animal welfare? Journal of Veterinary Behavior: Clinical Applications and Research 3 (5): 229-239 https://doi.org/10.1016/j.jveb.2008. 05.005.

Marsh, G.P. 1856. The camel; his organization, habits and uses/considered with reference to his introduction into the United States. Boston: Gould and Lincoln.

Mathan-Kumar, S., E.H. Johnson, and M.H. Tageldin. 2012. Wasm - An ethnoveterinary treatment of camels in Oman. In Proc. 3rd Conf. Intl. Soc. Camelid Res. Dev., January 29, 2012. Oman: Sultan Qaboos University.

Mattiello, S., M. Battini, G. De Rosa, F. Napolitano, and C. Dwyer. 2019. How can we assess positive welfare in ruminants? Animals 9 (10): 758 https://doi.org/1 0.3390/ani9100758

Matsuura A., M. Irimajiri, K. Matsuzaki, Y. Hiraguri, T. Nakanowatari, A. Yamazaki, K. Hodate. 2013. Method for estimating maximum permissible load weight for Japanese native horses using accelerometer-based analysis. Anim Sci J 84 (1): 75-81 https://doi.org/10.1111/j.1740-0929.2012.01041.x. Epub 2012 Jul 9.

McCorkle, C.M., and M. Martin. 1998. Parallels and potentials in animal and human ethnomedical technique. Agriculture and Human Values 15 (2): 139 144 https://doi.org/10.1023/a:1007482910691.

McCorkle, C.M., and E. Mathias-Mundy. 1992. Ethnoveterinary medicine in Africa. Africa 62 (01): 59-93 https://doi.org/10.2307/1160064. 
Mellor, D.J. 2004. Comprehensive assessment of harms caused by experimental, teaching and testing procedures on live animals. Alternatives to Laboratory Animals 32 (Suppl. 1): 453-457. https://doi.org/10.1177/026119290403201s73.

Mellor, D.J. 2012. Affective states and the assessment of laboratory-induced animal welfare impacts. Montreal: Alternatives to Animal Experimentations; 1: $445-449$

Mellor, D.J. 2017. Operational details of the Five Domains model and its key applications to the assessment and management of animal welfare. Animals 7 (12): 60. https://doi.org/10.3390/ani7080060.

Mellor, D.J., and N.J. Beausoleil. 2015. Extending the 'Five Domains' model for animal welfare assessment to incorporate positive welfare states. Animal Welfare 24 (3): 241-253. https://doi.org/10.7120/09627286.24.3.241.

Mellor, D.J., N.J. Beausoleil, K.E. Littlewood, A.N. McLean, P.D. McGreevy, B. Jones, and C. Wilkins. 2020. The 2020 Five Domains model: Including humananimal interactions in assessments of animal welfare. Animals 10 (10): 1870. https://doi.org/10.3390/ani10101870.

Mellor, D.J., E. Patterson-Kane, and K.J. Stafford. 2009. Animal welfare, grading compromise and mitigating suffering. In The Sciences of Animal Welfare, 72 94. Oxford: Wiley-Blackwell.

Mellor, D.J., and C.S.W. Reid. 1994. Concepts of animal well-being and predicting the impact of procedures on experimental animals. In Improving the wellbeing of animals in the research environment, ed. R.M. Baker, G. Jenkin, and D. J. Mellor, 3-18. Glen Osmond: Australian and New Zealand Council for the Care of Animals in Research and Teaching. Available at: https://org.uib.no/ dyreavd/harmbenefit/Concepts\%20of\%20animal\%20well-being\%20and\%2 Opredicting.pdf. Accessed 6 Nov 2020.

Mellor, D.J., and K.J. Stafford. 2001. Integrating practical, regulatory and ethical strategies for enhancing farm animal welfare. Australian Veterinary Journal 79 (11): 762-768. https://doi.org/10.1111/j.1751-0813.2001.tb10895.x.

Ministry of Agriculture and Fisheries. 1995. Husdyrvelfærd og husdyrproduktion. En rapport om forskning i velfæerd for husdyr [Animal welfare and animal production. A report on research in the welfare of livestock] Forskningssekretariatet, Landbrugs-og Fiskeriministeriet, København

Moore, J. 1921. Army veterinary service in war, chapter IX camels 149-157. London: Brown. https://doi.org/10.5962/bhl.title.54015.

Morin, D. 1996. Afar praise poetry: Orowwah. African Languages and Cultures (Supplement, (3)): 269-274 Retrieved February 14, 2021, from http://www. jstor.org/stable/586667.

Nagy, P., and J. Juhasz. 2016. Review of present knowledge on machine milking and intensive milk production in dromedary camels and future challenges. Tropical Animal Health and Production 48 (5): 915-926. https://doi.org/10.1 007/s11250-016-1036-3.

Nakyinsige, K., Y.B. Che Man, Z.A. Aghwan, I. Zulkifli, Y.M. Goh, F. Abu Bakar, H.A. Al-Kahtani, and A.Q. Sazili. 2013. Stunning and animal welfare from Islamic and scientific perspectives. Meat Science 95 (2): 352-361. Available at: https:// www.sciencedirect.com/science/article/abs/pii/S0309174013001265?via\%3 Dihub. https://doi.org/10.1016/j.meatsci.2013.04.006.

Namanda, A.T. 1998. Ethnoveterinary practice among the Gabbra nomadic pastoralists of northern Kenya. Journal Camel Practice and Research 5: 305-308.

New Zealand Government, 2018a. Code of welfare: Sheep and beef cattle. Available at: https://www.mpi.govt.nz/dmsdocument/1450-Sheep-and-BeefCattle-Animal-Welfare-Code-of-Welfare. Accessed 14 Jan 2021.

New Zealand Government, 2018b. Code of welfare: Painful husbandry procedures. Available at: https://www.mpi.govt.nz/dmsdocument/1443-Painful-Husba ndry-Procedures-Animal-Welfare-Code-of-Welfare. Accessed 14 Jan 2021.

National Equine Welfare Council. 2006. Code of practice for the tethering equines, 3rd revision Available at: https://www.donkeys.ie/legislation/NEWC-Code-ofPractice-for-Tethering-Equines-Nov-2006-Rev-1-300913.pdf.

National Farm Animal Care Council. 2013. Code of practice for the care and handling of beef cattle. Available at: http://www.nfacc.ca/pdf/english/BeefCa ttle1991.pdf. Accessed 14 Jan 2021.

Ohta, I. 1987. Livestock individual identification among the Turkana: The animal classification and naming in the pastoral livestock management. African Study Monographs 8 (1): 1-69.

OIE. 2012. Animal Welfare, Section 7. In Terrestrial AnimalHealth Code (2019) Volume 1. Paris: World Organisation for Animal Health (OIE) Available online at: https://www.oie.int/en/standard-setting/terrestrial-code/access-online/. Accessed 13 Jan 2021.

Padalino, B., L. Aubé, M. Fatnassi, D. Monaco, T. Khorchani, M. Hammadi, and G.M. Lacalandra. 2014. Could dromedary camels develop stereotypy? The first description of stereotypical behaviour in housed male dromedary camels and how it is affected by different management systems. PLoS One 9 (2): e89093. https://doi.org/10.1371/journal.pone.0089093.

Padalino, B., and L. Menchetti. 2021. The first protocol for assessing welfare of camels. Frontiers in Veterinary Science. 7: 631876. https://doi.org/10.3389/ fvets.2020.631876.

Pastrana, C.I., F.J.N. González, E. Ciani, C.J.B. Capote, and J.V.D. Bermejo. 2020. Effect of research impact on emerging camel husbandry, welfare and socialrelated awareness. Animals. 10 (5): 780. https://doi.org/10.3390/ani10050780.

Pinto Cebrián, F. 1997. Proverbios Saharauis, 282. Madrid: Miraguano Ediciones.

Plassio, E. 1912. /l cammello, 303. Milano: Manuali Hoepli.

POCTA Act. 2020. Prevention of Cruelty to Animals Act 1986, authorised version no. 096 no. 46 of 1986, Authorised version incorporating amendments as at 6 April 2020. Government of Australia. Available at: https://content.legislation. vic.gov.au/sites/default/files/2020-04/86-46aa096\%20authorised.pdf.

Pradeep, Dharm, and G.S. Tiwari. 2005. Fatigue assessment of Bikaneri camels in field work, 17-23. Draught Animal News No. 42, Centre for Tropical Veterinary Medicine University of Edinburgh.

Previti, A., B. Guercio, and A. Passantino. 2016. Protection of farmed camels (Camelus dromedarius): Welfare problems and legislative perspective. Animal Science Journal 87 (2): 183-189. https://doi.org/10.1111/asj.12446.

Qāsim ibn Ali ibn Mohammad ibn 'Ali al-Hariri al-Basri. 1236-1237. The Makamat of Hariri; copy decorated with paintings executed by Yahya ibn Mahmoud ibn Yahya ibn Aboul-Hasan ibn Kouvarriha al-Wasiti. National Library of France. Manuscripts Department. Arab 5847, Available at: http://gallica.bnffr/a rk:/12148/btv1b8422965p. Accessed 6 Nov 2020.

Ranjan, R., F. Tuteja, K. Kashinath, and N. Patil. 2017. A survey on traditional practices adopted for restraining camel in Rajasthan. The Indian Journal of Animal Sciences 87 (1):. http://epubs.icar.org.in/ejournal/index.php/IJAnS/a rticle/view/66940.

Rathore, G.S. 1986. Camels and their management. Indian Council of Agricultural Research. New Delhi.

Raziq, A., K. Verdier, and M. Younas. 2010. Ethnoveterinary treatments by dromedary camel herders in the Suleiman Mountainous Region in Pakistan: An observation and questionnaire study. Journal of Ethnobiology and Ethnomedicine 6 (1): 16. https://doi.org/10.1186/1746-4269-6-16.

Roy, A.K., A.K. Rai, and N.D. Khanna. 1992. Draught capacity and fatigue symptoms under ploughing stress in camel. Indian Journal of Animal Sciences. 62 (4): 387-389.

Roy, A.K., and G.S. Tiwari. 2010. Work performance of dromedary camels on multipurpose tool carrier. Journal of Camel Practice and Research 17 (2): 199-200.

Schams, D., G. Baumann, and W. Leidl. 1982. Oxytocin determination by radioimmunoassay in cattle. II. Effect of mating and stimulation of the genital tract in bulls, cows and heifers. Acta Endocrinologica (Copenh). 99 (2): 218223. https://doi.org/10.1530/acta.0.0990218.

Schapera, I., and B. Farrington. 1933. The early Cape Hottentots. Vol. 14. Cape Town: Van Riebeeck Society.

Schillhorn van Veen, T.W. 1997. Sense or nonsense? Traditional methods of animal parasitic disease control. Veterinary Parasitology 71 (2-3): 177-194. https://doi.org/10.1016/s0304-4017(97)00031-9.

Schwabe, C., and I. Kuojok. 1981. Practices and beliefs of the traditional Dinka healer in relation to provision of modern medical and veterinary services for the southern Sudan. Human Organization 40 (3): 231-238 https://doi.org/10.1 7730/humo.40.3.603068x72h171362.

Schwartz, H. J., and M. Dioli. 1992. The one-humped camels (Camelus dromedarius) in Eastern Africa: A pictorial guide to diseases, health care and management. Verlag Josef, Scientific books D-6992 Weikersheim Germany.

Seele, B.C. 2017. Conservation implications of ethnoveterinary knowledge: A Mongolian case study. Thesis. Stellenbosch University, Stellenbosch, South Africa Available at: http://scholar.sun.ac.za/handle/10019.1/101386.

Seid, A., M.Y. Kurtu, and M. Urge. 2017. Slaughter practices and composition of dromedary camel (Camelus dromedarius) meat in relation to age and body condition in Eastern Ethiopia. Journal of Agriculture and Environment for International Development. 111 (1): 191-206.

Serpell, J.A. 2004. Factors influencing human attitudes to animals and their welfare. Animal Welfare 13: 145-151. https://www.researchgate.net/publica tion/263077760_Factors_Influencing_Human_Attitudes_to_Animals_and_ Their_Welfare.

Sierksma, F. 1962. 111. Two pastoral customs in Tibet. Man 62: 70 https://doi. org/10.2307/2796428. Accessed 15 Dec 2020.

Silver, I.A., P.N. Brown, A.E. Goodship, L.E. Lanyon, K.G. McCullagh, G.C. Perry, and I. F. Williams. 1983. A clinical and experimental study of tendon injury, healing 
and treatment in the horse. Equine Veterinary Journal Supplement 1: 1-43. PMID: 9079042

Simonsen, H.B. 1996. Assessment of animal welfare by a holistic approach: Behaviour, health and measured opinion. Acta Agriculturae Scandinavica Sect A Animal Science Suppl 27: 91-96.

Sowayan, S.A. 1985. Nabati poetry: The oral poetry of Arabia, 234. Berkeley: University of California Press; https://doi.org/10.1525/9780520335073.

Steel, J.H. 1890. A manual of the diseases of the camel and of his management and uses. Indian Veterinary Manuals, III. Madras: Lawrence Asylum Press. https://doi.org/10.1186/s13570-021-00221-5.

Stenmark, M. 2002. Environmental ethics and policy-making. London: Routledge. https://doi.org/10.4324/9781315256320.

Thomas, B. 1932. Arabia felix: across the empty quarter of Arabia, 397 pp. London: Jonathan Cape.

Uerpmannh, H.P. 1999. Camel and horse skeletons from protohistoric graves at Mleiha in the Emirate of Sharjah. Arabian Archaeology and Epigraphy 10 (1): 102-118. https://doi.org/10.1111/j.1600-0471.1999.tb00131.x.

Vaarst, M., and H.F. Alrøe. 2012. Concepts of animal health and welfare in organic livestock systems. Journal of Agricultural and Environmental Ethics 25 (3): $333-$ 347. https://doi.org/10.1007/s10806-011-9314-6.

Vaarst, M., and E.S. Kristensen. 2000. Muligheder for forbedringer. \{Options for improvement\}. In Sundhed, dyrevelfærd og medicinanvendelse ved omlæegning til økologisk mælkeproduktion, ed. E.S. Kristensen and S.M. Thamsborg, 135144 FØJO-rapport nr. 6. Forskningscenter for Økologisk Jordbrug, Foulum.

Volpato, G., and P. Howard. 2014. The material and cultural recovery of camels and camel husbandry among Sahrawi refugees of Western Sahara. Pastoralism: Research, Policy and Practice 4 (1): 7. https://doi.org/10.1186/s13 570-014-0007-4.

Volpato, G., S.M. Lamin Saleh, and A. Di Nardo. 2005. Ethnoveterinary of Sahrawi pastoralists of Western Sahara: Camel diseases and remedies. Journal of Ethnobiology and Ethnomedicine 11: 54.

Volpato, G., and R.K. Puri. 2014. Dormancy and revitalization: The fate of ethnobotanical knowledge of camel forage among Sahrawi nomads and refugees of Western Sahara. Ethnobotany Research and Applications, [S.I.] 12: 183-210. Available at: http://ethnobotanyjournal.org/era/index.php/era/a rticle/view/924. Accessed 18 Jan 2021.

Waddington, C.H. 1974. Horse brands of the Mongolians: a system of signs in a nomadic culture. American Ethnologist 1 (3): 471-488. https://doi.org/10.152 5/ae.1974.1.3.02a00050.

Weary, D.M., and J.A. Robbins. 2019. Understanding the multiple conceptions of animal welfare. Animal Welfare 28 (8): 33-40. https://doi.org/10.7120/096272 86.28.1.033

Welfare Quality Network. 2009. Assessment Protocols. Available online at: http:// www.welfarequalitynetwork.net/en-us/reports/assessment-protocols. Accessed 13 Jan 2021

Western, D., and V. Finch. 1986. Cattle and pastoralism: Survival and production in arid lands. Human Ecology 14 (1): 77-94. https://doi.org/10.1007/ BF00889211.

WHO. 2017. Collection and storage of whole blood. In WHO Expert Committee on Biological Standardization, sixty-seventh report. WHO technical report series; no. 1004, 267. Geneva: Annex 5: Guidelines for the production, control and regulation of snake antivenom immunoglobulins. Available at: https://www. who.int/publications/i/item/9789241210133.

Wilson, R.T. 1984. The camel. London and New York: Longman.

Xange, A.A., and A.C. Abokar. 1987. The camel in Somali oral traditions. Mogadishu: Somali Academy of Sciences and Arts; Nordiska Afrikainstitutet, 103. Available at: http://urn.kb.se/resolve?urn=urn:nbn:se:nai:diva-658.

Zander, K., and U. Hamm. 2010. Consumer preferences for additional ethical attributes of organic food. Food Quality and Preferences 21 (5): 495-503. https://www.academia.edu/16270249/Consumer_preferences_for_additional_ ethical_attributes_of_organic_food. https://doi.org/10.1016/j.foodqual.2010. 01.006

Zappaterra, M., L. Menchetti, L. Nanni Costa, and B. Padalino. 2021. Do camels (Camelus dromedarius) need shaded areas? A case study of the camel market in Doha. Animals 11 (2): 480. https://doi.org/10.3390/ani1 1020480.

\section{Publisher's Note}

Springer Nature remains neutral with regard to jurisdictional claims in published maps and institutional affiliations.

\section{Submit your manuscript to a SpringerOpen ${ }^{\circ}$ journal and benefit from:}

- Convenient online submission

- Rigorous peer review

- Open access: articles freely available online

- High visibility within the field

- Retaining the copyright to your article

Submit your next manuscript at $\boldsymbol{\nabla}$ springeropen.com 